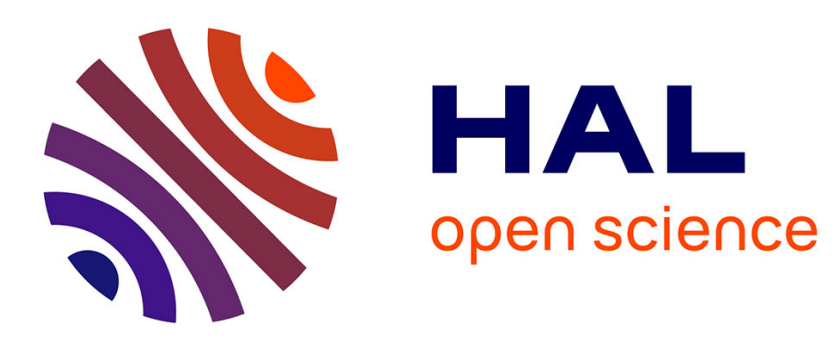

\title{
Mineral dust transport to the Sierra Nevada, California: Loading rates and potential source areas
}

\author{
W.C Vicars, J. O. Sickman
}

\section{To cite this version:}

W.C Vicars, J. O. Sickman. Mineral dust transport to the Sierra Nevada, California: Loading rates and potential source areas. Journal of Geophysical Research, 2011, 116, pp.G01018. 10.1029/2010JG001394 . insu-00605102

\section{HAL Id: insu-00605102 https://hal-insu.archives-ouvertes.fr/insu-00605102}

Submitted on 10 Mar 2021

HAL is a multi-disciplinary open access archive for the deposit and dissemination of scientific research documents, whether they are published or not. The documents may come from teaching and research institutions in France or abroad, or from public or private research centers.
L'archive ouverte pluridisciplinaire HAL, est destinée au dépôt et à la diffusion de documents scientifiques de niveau recherche, publiés ou non, émanant des établissements d'enseignement et de recherche français ou étrangers, des laboratoires publics ou privés. 


\title{
Mineral dust transport to the Sierra Nevada, California: Loading rates and potential source areas
}

\author{
William C. Vicars ${ }^{1,2}$ and James O. Sickman ${ }^{1}$ \\ Received 19 April 2010; revised 25 September 2010; accepted 7 December 2010; published 17 February 2011.
}

[1] The transport and deposition of aeolian dust represents an important material input pathway for many marine and terrestrial ecosystems and may be an ecologically significant source of exogenous phosphorus $(\mathrm{P})$ to alpine lakes. In order to assess the abundance and elemental composition of atmospheric mineral dust over the Sierra Nevada of California, we collected size-fractionated atmospheric particulate matter (PM) samples during July 2008 to March 2009 at a mixed conifer site located in Sequoia National Park. PM concentrations were at their highest levels during the dry season, averaging $8.8 \pm 3.7$ and $11.1 \pm 7.5 \mu \mathrm{g} \mathrm{m}^{-3}$ for the coarse $\left(1 \mu \mathrm{m}<\mathrm{D}_{\mathrm{a}}<15 \mu \mathrm{m}\right)$ and fine $\left(\mathrm{D}_{\mathrm{a}}<1 \mu \mathrm{m}\right)$ fractions, respectively, while winter months were characterized by low $\left(<1 \mu \mathrm{g} \mathrm{m}^{-3}\right) \mathrm{PM}$ concentrations in both size fractions. Using $\mathrm{Al}$ as a diagnostic tracer for mineral aerosol, we observed a significant and uniform contribution (50-80\%) from aeolian dust to the total coarse PM load, whereas submicron particles contained comparatively little crustal material (7-33\%). The mass concentrations of elements ( $\mathrm{Fe}, \mathrm{Ca}, \mathrm{Mg}, \mathrm{P}$, and $\mathrm{V}$ ) in the coarse $\mathrm{PM}$ fraction were significantly correlated with $\mathrm{Al}$ throughout the study, and coarse PM exhibited elemental signatures that were temporally consistent and distinguishable from those of other sites. Conversely, higher elemental enrichments were observed in the fine PM fraction for Fe, V, and P, indicating a greater contribution from anthropogenic emissions to the fine particle load. $\mathrm{Fe} / \mathrm{Al}$ and $\mathrm{Fe} / \mathrm{Ca}$ ratios suggest a mixture of mineral dust from regional agricultural activities and long-range transport of mineral dust from Asia. Asian sources comprised 40-90\% of mineral dust in July 2008 and then declined to between 10 and 30\% in August and early September.

Citation: Vicars, W. C., and J. O. Sickman (2011), Mineral dust transport to the Sierra Nevada, California: Loading rates and potential source areas, J. Geophys. Res., 116, G01018, doi:10.1029/2010JG001394.

\section{Introduction}

[2] Atmospheric mineral dust comprises the largest component of total aerosol mass over continental regions and has recently attracted a great deal of scientific interest due to its potential impact on atmospheric chemistry and global radiative forcing. Atmospheric dust acts as condensation nuclei for cloud formation [Yin et al., 2002], supplies limiting nutrients to support primary production in marine and terrestrial ecosystems [Bishop et al., 2002; Chadwick et al., 1999; Graham and Duce, 1982; Mills et al., 2004], provides reaction surfaces for gas-phase atmospheric chemical processes [Zhang and Carmichael, 1999], and influences the global radiation balance through its interaction with long- and short-wave radiation [Sokolik et al., 2001]. Furthermore, there is increasing evidence that the transport of mineral dust to high-elevation areas may have considerable biogeochemical implications for

\footnotetext{
${ }^{1}$ Department of Environmental Sciences, University of California, Riverside, California, USA.

${ }^{2}$ Now at Laboratoire de Glaciologie et Géophysique de l'Environment, Université Joseph Fourier, CNRS, St. Martin d'Héres, France.

Copyright 2011 by the American Geophysical Union. 0148-0227/11/2010JG001394
}

mountain ecosystems [Psenner, 1999]. The deposition of phosphorus, an element which is predominantly associated with crustal material in the atmosphere, may be largely controlled by dust at some remote high-elevation sites, representing a significant nutrient input pathway for high-elevation lakes [Morales-Baquero et al., 2006]. However, there is a relative scarcity of information on the size distribution and chemical composition of dust aerosol particles in remote areas, and thus there is large uncertainty regarding the possible impacts of atmospheric dust loading in high-elevation regions [Prospero, 1999].

[3] Atmospheric particulate matter (PM) at any site is composed of materials from nearby areas as well as particles transported over long distances. The majority of mineral material emitted into the atmosphere from land exists in the coarse (1-100 $\mu \mathrm{m}$ diameter) aerosol fraction. However, due to the rapid deposition of the largest particles $(>10 \mu \mathrm{m})$, the size distribution of a mineral aerosol is altered as it is transported from its source region, resulting in a progressively smaller mean diameter. Consequently, mineral aerosols that have undergone long-distance transport are composed mostly of particles in the 1-3 $\mu \mathrm{m}$ size range [Mori et al., 2003; VanCuren and Cahill, 2002; Zhao et al., 2003], while mineral 


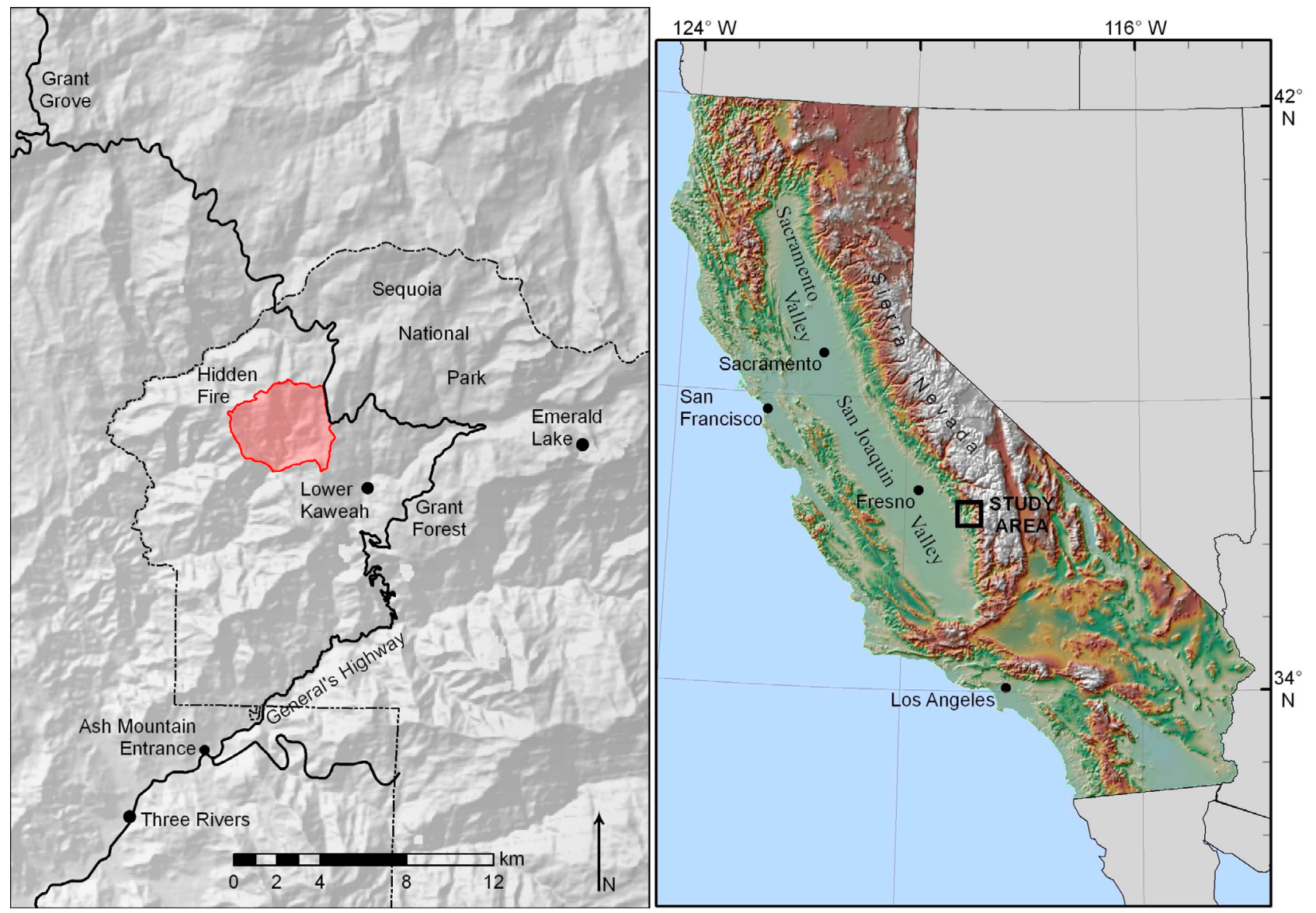

Figure 1. Map of California and location of the Lower Kaweah sampling site in the southern Sierra Nevada.

aerosols from local or regional sources are typically larger than $3 \mu \mathrm{m}$. Atmospheric mineral aerosols transported from the world's major desert regions have been detected in the 1$3 \mu \mathrm{m}$ size range in the free troposphere in nearly every part of the world [Arimoto et al., 1995; Bergametti et al., 1989; Prospero, 1999]. For example, the atmospheric transport of mineral dust and associated pollutants from the Asian continent are a significant contributor to aerosol loading throughout the Pacific basin. Asian dust can reach relatively high concentrations above the marine boundary layer in the western United States, representing as much $85 \%$ of the total atmospheric burden of particulate matter at some sites [VanCuren, 2003]. Trans-Pacific dust transport has been found to be particularly relevant in high-elevation regions, which typically represent free-tropospheric conditions due to the limited transport of lowland air pollutants and predominance of upper air subsidence [VanCuren et al., 2005]. This makes high-elevation sites of the western U.S. ideal locations for studying the transport of Asian dust [Cutten et al., 2003].

[4] The input of mineral dust and associated pollutants is likely to have broad hydrological and biogeochemical consequences in high-elevation regions [Painter et al., 2007; Neff et al., 2008; Seinfeld et al., 2004]. For example, the deposition of black carbon associated with the Asian continental plume has been observed to significantly decrease snow albedo in the Arctic [Park et al., 2005]. A similar effect in the western U.S. could have implications for runoff timing and water supply for millions of people depending on snowpack water [Pupacko, 1993]. Dust deposition may also represent an ecologically significant input of nutrients, acids, and base cations to high-elevation lakes, which are sensitive to the effects of atmospheric deposition due to their low nutrient content and limited acid-neutralizing capacity [Fenn et al., 2003]. Long-term data from the Sierra Nevada, California suggest that lakes are experiencing eutrophication in response to increased P loading [Sickman et al., 2003]; however, there have been very few measurements of atmospheric P concentrations made in the western U.S. that can be used to assess whether these biogeochemical trends are being driven by atmospheric processes.

[5] In this study, we report measurements of the mass concentration and elemental composition of size-fractionated atmospheric PM sampled at a mixed-conifer site in the southern Sierra Nevada during 2008-2009. This detailed analysis, which involves the use of elemental mass concentrations ( $\mathrm{Al}, \mathrm{Fe}, \mathrm{Ca}, \mathrm{Mg}, \mathrm{V}$, and $\mathrm{P}$ ) and relative elemental abundances as diagnostic tracers to identify and characterize atmospheric mineral dust, is one of the first to examine the nature and chemical composition of airborne dust in the Sierra Nevada of California. A secondary objective of the study was to quantify the relative extent of trans-Pacific transport of aeolian materials from Asia compared to the transport of dust from local or regional sources during the summer growing season in the Sierra Nevada, when biological impacts of dust 


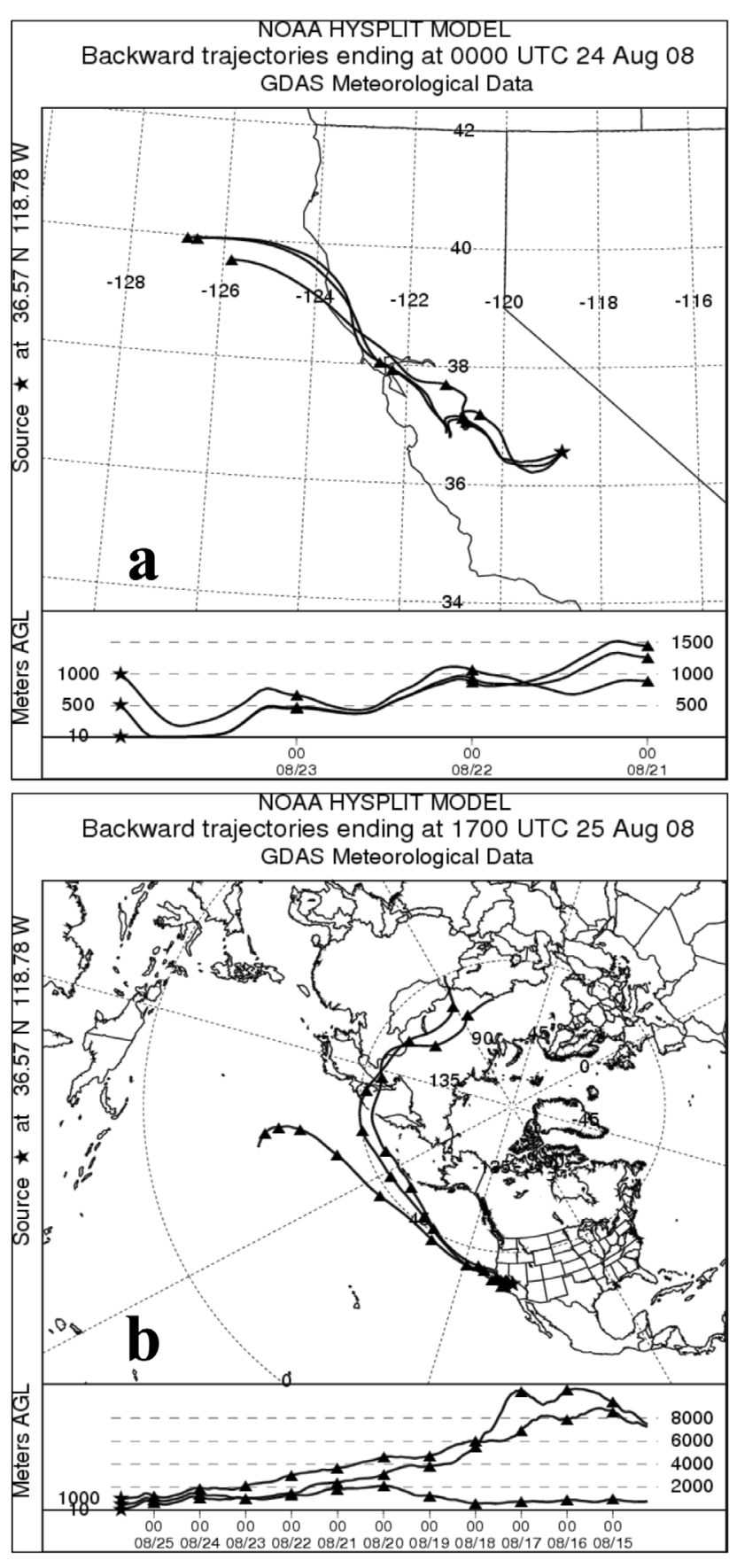

Figure 2. (a) Three day and (b) 11 day backward trajectories of the air masses reaching the Lower Kaweah site in late August, showing the most common regional and long-range transport patterns, respectively. AMBT data was obtained from the National Oceanic and Atmospheric Administration (NOAA) GDAS database using the hybrid single-particle Lagrangian integrated trajectory (HYSPLIT) model [Draxier and Hess, 1998] and is described in greater detail by Vicars et al. [2010]. AMBTs were calculated at 10, 500, and $1000 \mathrm{~m}$ above ground level.

deposition on aquatic ecosystems may be greatest. We hypothesize that regional PM sources (San Joaquin Valley agriculture, Sierra Nevada forest fires, and forest biogenic particles) will overwhelm inputs from distance sources such as Asia during the late summer and autumn in the Sierra Nevada, while Asian dust will be a relatively stronger source of PM during early summer. Furthermore, we hypothesize that mineral dust is the primary source of atmospheric $\mathrm{P}$ over the Sierra Nevada, with implications for nutrient delivery to remote aquatic ecosystems.

\section{Materials and Methods}

\subsection{Site Description and Meteorology}

[6] Atmospheric PM sampling was conducted at the Lower Kaweah monitoring station $\left(36^{\circ} 33^{\prime} 58^{\prime \prime} \mathrm{N}, 118^{\circ} 46^{\prime}\right.$ $40^{\prime \prime} \mathrm{W}$; $1905 \mathrm{~m}$ above mean sea level; Figure 1), located in Sequoia National Park, in the southern Sierra Nevada of California. The Lower Kaweah station is situated at the top of a steep cliff on a west facing rocky outcrop in a mixed conifer forest, about $1500 \mathrm{~m}$ from the nearest major road, and is therefore relatively sheltered from nearby sources of anthropogenic aerosol particles. The site is an air quality and visibility monitoring station operated by the National Park Service, Air Resources Division and has been the location of previous air pollution studies [Bytnerowicz et al., 2002].

[7] The results of 3 and 11 day air mass back trajectory (AMBT) simulations obtained with the NOAA HYSPLIT model (Figures $2 \mathrm{a}$ and $2 \mathrm{~b}$ ) indicate that air masses reaching the Lower Kaweah site most frequently arrived from a westerly, or northwesterly direction, typically passing over the San Francisco Bay area and the San Joaquin Valley en route (Figure 2a); this is a very common pattern of air mass transport in central California during the dry season [Leidner et al., 2001; Vicars et al., 2010]. These air masses may transport substantial quantities of atmospheric PM due to the buildup of particulate emissions in the San Joaquin Valley associated with "Fresno Eddy" recirculation events, which is the primary cause of impaired air quality and reduced visibility within Sequoia National Park during nonwinter months [Carroll and Dixon, 2002]. However, an atmospheric boundary layer exists at an elevation lower than that of the sampling site during most of summer and autumn [Cutten et al., 2003; Ewell et al., 1989], which tends to restrict up-valley aerosol transport to a few hours a day. Therefore, the Lower Kaweah site is likely to be impacted episodically throughout the dry season by both regional dust emissions transported upslope from the San Joaquin Valley and long-range dust transport associated with the marine boundary layer. The trans-Pacific movement of air masses from the vicinity of the Asian continent and associated delivery of free-tropospheric air to our highelevation sampling site was confirmed by 11 day AMBT data (Figure $2 \mathrm{~b}$ ) and was found to occur regularly throughout the sampling period.

[8] The mean daily averaged temperature, relative humidity, and wind speed during the study period were $16.8 \pm 4.3^{\circ} \mathrm{C}$, $45 \pm 15 \%$, and $1.7 \pm 0.2 \mathrm{~m} \mathrm{~s}^{-1}$, respectively. Topographic winds at the Lower Kaweah site followed a predictable pattern [Ewell et al., 1989] of daytime up-valley winds and nighttime down-valley winds, with the former typically transporting a much greater aerosol load. There were no significant precipitation events during the July-October 2008 period, with the exception of a small $(8 \mathrm{~mm})$ snow event in early October. However, snow events were common during the NovemberMarch period, with approximately $500 \mathrm{~mm}$ of snow falling during this time. 


\subsection{Aerosol Sampling}

[9] Dichotomous PM sampling was conducted using Stacked Filter Unit (SFU) samplers [Hopke et al., 1997], which collected coarse and fine PM samples integrated over 24 or $48 \mathrm{~h}$. The SFUs were equipped with flow regulators and were typically operated at a rate of $20 \mathrm{~L}$ per minute. The SFUs used a multiple filter holder to fractionate aerosols, which were collected on $47 \mathrm{~mm}$ Nuclepore polycarbonate membrane filters. A $5 \mu \mathrm{m}$ pore size filter captured coarse PM $\left(1 \mu \mathrm{m}<\mathrm{D}_{\mathrm{a}}<15 \mu \mathrm{m}\right)$, while fine PM $\left(\mathrm{D}_{\mathrm{a}}<1 \mu \mathrm{m}\right)$ passed through and was deposited on a polycarbonate membrane filter with pore size of $0.4 \mu \mathrm{m}$. The SFU samplers were equipped with a sampling inlet cover that excluded particles larger than $15 \mu \mathrm{m}$ in diameter. This inlet was positioned approximately $3 \mathrm{~m}$ above the ground.

[10] A total of 43 SFU samples were collected between 2 July and 27 October 2008, and nine samples were collected between 23 December 2008 and 25 March 2009. Field blanks for SFU substrates were collected at regular intervals and were subjected to the same storage, handling, and analytical procedures as field samples. After sampling, all filters were folded and placed into clean petri dishes and stored at $-20^{\circ} \mathrm{C}$. Particle mass concentrations were then determined via gravimetric analysis of filters [Vicars et al., 2010]. In this method, SFU filters were weighed before and after field deployment using a Sartorious ME-5 microbalance. Precautions were taken to minimize possible variations in filter mass caused by differences in moisture content and electrostatic charge. The method detection limit for particle mass on sampling membranes was $20 \mu \mathrm{g}$. Based on the average sampling time and flow rate used in our study, this detection limit corresponds to atmospheric PM concentrations of about $1 \mu \mathrm{g} \mathrm{m}^{-3}$.

\subsection{Laboratory Analysis}

[11] Concentrations of dust-associated elements (Al, Fe, $\mathrm{Ca}$, and $\mathrm{Mg}$ ) were determined for coarse and fine SFU samples after acid digestion using inductively coupled atomic emission spectrometry (ICP-AES, Optima 3000 DV, PerkinElmer ${ }^{\mathrm{TM}}$ Instruments, U.S.) while concentrations of V, which is commonly regarded a tracer for emissions derived from fossil fuel combustion [Sholkovitz et al., 2009], were determined using quadrupole inductively coupled mass spectrometry (ICP-MS, Agilent ${ }^{\mathrm{TM}}$ 7500ce, Agilent ${ }^{\mathrm{TM}}$ Technologies, U.S.). In the acid digestion procedure, filters were placed into Teflon vessels (which were thoroughly precleaned via sonication in $50 \% \mathrm{HNO}_{3}$ and kept stored in a $5 \% \mathrm{HNO}_{3}$ acid bath when not in use) to which $6 \mathrm{ml} 70 \% \mathrm{HNO}_{3}$ and $6 \mu \mathrm{l} \mathrm{HF}$ [Kulkarni et al., 2007] were added. The filters were then digested in a two-step process using a microwave heating system (CEM MARS 5, CEM ${ }^{\text {TM }}$ Corporation, U.S.). In the first step, the temperature was ramped to $200^{\circ} \mathrm{C}$ (with a pressure setting of $1379 \mathrm{kPa}$ ) and allowed to dwell for $20 \mathrm{~min}$, thus ensuring the complete dissolution of the mineral aerosol particles and filter [Pekney and Davidson, 2005]. The vessels were then removed from the microwave, cooled for $1 \mathrm{~h}$ in a freezer, and then opened and allowed to vent. At this time, $56 \mu \mathrm{l}$ of a $5 \%$ boric acid solution was added to each vessel to ensure the complete complexation of any free $\mathrm{F}$ - in the solution [Swami et al., 2001]. The Teflon-lined vessels were then recapped, placed back into the microwave and heated again to $200^{\circ} \mathrm{C}(1379 \mathrm{kPa})$ followed by a 20 min dwell time. The acid extract was then transferred to a clean centrifuge tube and diluted with $18.2 \mathrm{M} \Omega$ deionized water to a final volume of $85 \mathrm{~mL}$. Elemental concentrations derived from ICP-AES and ICP-MS were corrected for field blanks (i.e., field blank filters plus analytical reagents). Based on the standard deviation of the blank concentrations and average volume of air filtered for each sample $\left(\sim 43 \mathrm{~m}^{3}\right)$, method detection limits were determined for atmospheric elemental concentrations $(33,20,12,6$, and $0.035 \mathrm{ng} \mathrm{m}^{-3}$ for $\mathrm{Al}, \mathrm{Ca}, \mathrm{Fe}, \mathrm{Mg}$, and $\mathrm{V}$, respectively). In order to confirm the effectiveness of the digestion procedure used in this study, a recovery study was conducted using an atmospheric PM reference material (SRM 2783, Air Particulate Matter on Filter Media) provided by the National Institute of Standards and Technology [Freitas et al., 2004]. The certified particle loading value for each SRM 2783 filter is $485 \mu \mathrm{g}$, which is in the same range of the filter samples collected during the study $(100-500 \mu \mathrm{g})$. Recoveries of elements in the reference material via digestion and ICP-MS analysis averaged 96, $102,107,98$, and $109 \%(\mathrm{n}=2)$ for $\mathrm{Al}, \mathrm{Ca}, \mathrm{Fe}, \mathrm{Mg}$, and $\mathrm{V}$, respectively, indicating that our digestion method was sufficiently robust for the elements reported in this study.

[12] Total P was determined on SFU filter samples using a digestion procedure adapted from Chen et al. [2006]. Filters were combusted in a closed container overnight at $550^{\circ} \mathrm{C}$ and then extracted via sonication for $12 \mathrm{~h}$ with $10 \mathrm{~mL}$ of trace metal grade $1 \mathrm{~N} \mathrm{HCl}$. Extracts were neutralized to pH 7 with reagent grade $10 \mathrm{~N} \mathrm{NaOH}$ and carried through the molybdenum blue colorimetric method, using a Varian Cary 50 spectrophotometer and $5 \mathrm{~cm}$ quartz cell. The method detection limit obtained for TP was approximately $0.06 \mu \mathrm{mol} \mathrm{L}^{-1}\left(0.5 \mathrm{ng} \mathrm{m}^{-3}\right.$ in aerosols $)$. TP values for blanks (i.e., blank filter and reagents) were consistently below the method detection limit. There is presently no certified atmospheric PM reference material available for P; therefore, the accuracy of the TP analysis procedure used in this study was checked against a marine sediment reference material (SRM 2702, Inorganics in Marine Sediment) provided by the National Institute of Standards and Technology. SRM 2702 was included in all analytical runs and recoveries averaged $98 \pm 5 \%(n=33)$.

\section{Results}

\subsection{Coarse and Fine Particle Mass}

[13] Temporal variations in the gravimetric mass concentrations of coarse $\left(1<\mathrm{D}_{\mathrm{a}}<15 \mu \mathrm{m}\right)$ and fine $\left(\mathrm{D}_{\mathrm{a}}<1 \mu \mathrm{m}\right)$ mode PM are shown in Figures $3 \mathrm{a}$ and $3 \mathrm{~b}$, respectively, while average PM mass values are summarized in Table 1 for aggregated periods of the sampling campaign. Dry season total PM concentrations $\left(\mathrm{D}_{\mathrm{a}}<15 \mu \mathrm{m}\right)$ measured in this study ranged between 6 and $65 \mu \mathrm{g} \mathrm{m}^{-3}$, with a mean value and standard deviation of $20 \pm 10 \mu \mathrm{g} \mathrm{m}^{-3}$. Particle mass concentration exhibited substantial variability, particularly the fine particle load, which ranged from 3 to $49 \mu \mathrm{g} \mathrm{m}^{-3}$ during the summer dry season. This variability is particularly striking during the period 16-23 September, when maximum particulate loads were observed during a local wildfire called the Hidden Fire. The Hidden Fire occurred 

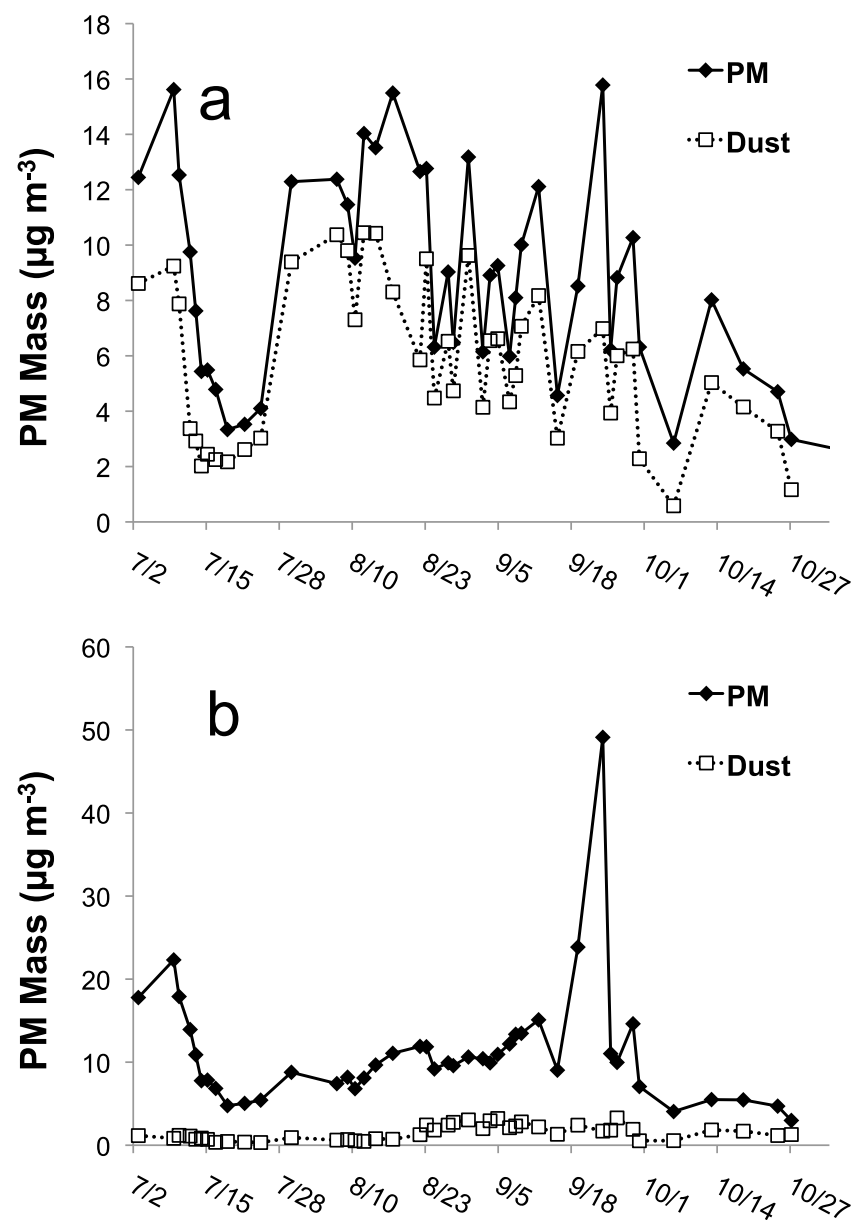

Figure 3. Temporal variability in total PM and estimated dust mass concentrations for (a) coarse and (b) fine filter samples.

approximately $10 \mathrm{~km}$ from the sampling site (Figure 1) and was the largest lightning-caused forest fire to burn in Sequoia National Park in decades, consuming 3700 acres between 10 September and 1 October, and producing large quantities of airborne PM. Wildfire emissions led to especially high fine PM concentrations ( $49 \mu \mathrm{g} \mathrm{m}^{-3}$; Figure $\left.3 \mathrm{~b}\right)$, although coarse PM $\left(\sim 16 \mu \mathrm{g} \mathrm{m}^{-3}\right)$ also spiked during this time, most likely due to the entrainment of local dust and large carbonaceous particles during the fire [Mahowald et al., 2005]. Coarse PM concentrations reached their highest sustained values during the month of August, when the fine to coarse particle ratio was below unity for most of the month. However, for the majority of the sampling period, there was typically a greater concentration of fine PM mass, presumably due to the upslope transport of submicron particles produced from combustion and other anthropogenic activities in the San Joaquin Valley. Size distribution data reported by Vicars et al. [2010] for the period July-October 2008 indicates that $50-70 \%$ of the primary aerosol particle mass at the Lower Kaweah site was composed of particles in the 1.0-3.2 $\mu \mathrm{m}$ size range, while particles larger than $10 \mu \mathrm{m}$, which have brief atmospheric residence times and are thus more likely to have originated from local sources, contributed only $5-15 \%$ of the total PM mass. This obser- vation suggests that long-range and regional transport pathways (i.e., mineral aerosol transport from Asia and central California) are important factors determining coarse PM mass concentrations at Lower Kaweah.

[14] PM concentrations in both the coarse and fine fractions reached their lowest dry season values at the end of October (Figures $3 \mathrm{a}$ and $3 \mathrm{~b}$ ) and very low mass concentration values were observed throughout the winter, presumably due to thorough scavenging of atmospheric particles by falling snow coupled with weakened transport from off site. In fact, PM concentrations were below detection limit $\left(1 \mu \mathrm{g} \mathrm{m}^{-3}\right)$ in both size fractions for the entire period December-February (Table 1), highlighting the importance of the dry season for aerosol transport to the Sierra Nevada. Due to the low relative abundance of PM observed during the winter months, the nine samples collected during this period have been largely neglected in the following analysis and means and standard deviations given throughout the text are for the dry season (JulyOctober) unless otherwise stated.

\subsection{Aerosol Contributions From Mineral Dust}

[15] In order to estimate the mass concentration of aeolian dust, we used $\mathrm{Al}$ as a diagnostic tracer of atmospheric crustal material [Guieu et al., 2002; Liu et al., 2009; Markaki et al., 2003]. This approach assumes that the atmospheric Al detected during the sampling period was entirely of mineral origin, and that $\mathrm{Al}$ derived from anthropogenic activities was an insignificant source of atmospheric loading, which is a reasonable assumption for a remote, high-elevation site [Kumar and Sarin, 2009]. Using the average Al abundance (8.04\%) of upper continental crust (UCC) [ Taylor and McLennan, 1995] as an index of mineral dust, the mass concentration of mineral dust was calculated for each sampling period, and its contribution to total PM mass in the coarse and fine fractions was estimated as

$$
\%{ }_{0 u s t}=\frac{\left[A l_{P M}\right]}{0.0804^{*}[P M]}
$$

where $\mathrm{Al}_{\mathrm{PM}}$ is $\mathrm{Al}$ mass $\left(\mathrm{ng} \mathrm{\textrm {m } ^ { - 3 }}\right)$ in each aerosol sample, 0.0804 is the average abundance of $\mathrm{Al}$ in the UCC, and PM is the particle mass concentration $\left(\mu \mathrm{g} \mathrm{m}^{-3}\right)$ for the sample. Mineral dust dominated the coarse PM fraction for most of the sampling period, representing $60-80 \%$ of total coarse particle mass (Figure 3a). Dust concentrations in the coarse PM fraction were highest (9-10 $\mu \mathrm{g} \mathrm{m}^{-3}$ ) during the period 117 August 2008. Samples collected during this period averaged $80 \%$ mineral dust by mass, and are deemed particularly useful in this study for the elemental characterization of dust transported to the southern Sierra Nevada. These samples will henceforth be referred to as "high dust" samples. Mineral dust contributed much less to the total mass of submicron particles, with a fractional contribution ranging between 7 and $33 \%\left(0.3-3 \mu \mathrm{g} \mathrm{m}^{-3}\right.$; Figure $\left.3 \mathrm{~b}\right)$.

[16] The association of the elements measured in this study with mineral dust, which was suggested by their coarse size distribution, was confirmed through the use of linear regression analysis (Table 2). Significant linear relationships ( $p<$ 0.05 ) between measured elements and $\mathrm{Al}$ (i.e., mineral dust) were observed in both size fractions, with somewhat stronger correlations (i.e., higher $r^{2}$ values) exhibited in the coarse PM 
Table 1. Mean Mass and Elemental Concentrations for Coarse, Fine, and Total Atmospheric PM at the Lower Kaweah Study Site From July 2008 to March 2009

\begin{tabular}{|c|c|c|c|c|c|c|c|c|}
\hline & $\mathrm{n}$ & $\operatorname{Mass}\left(\mu \mathrm{g} \mathrm{m}^{-3}\right)$ & Dust $\left(\mu \mathrm{g} \mathrm{m}^{-3}\right)$ & $\mathrm{Al}\left(\mathrm{ng} \mathrm{m}^{-3}\right)$ & $\mathrm{Ca}\left(\mathrm{ng} \mathrm{\textrm {m } ^ { - 3 }}\right)$ & $\mathrm{Fe}\left(\mathrm{ng} \mathrm{\textrm {m } ^ { - 3 }}\right)$ & $\operatorname{Mg}\left(\operatorname{ng~m}^{-3}\right)$ & $\mathrm{V}\left(\mathrm{ng} \mathrm{\textrm {m } ^ { - 3 }}\right)$ \\
\hline \multicolumn{9}{|c|}{ Coarse } \\
\hline $7 / 2-7 / 16$ & 8 & 9.2 & 4.8 & 389 & 180 & 253 & 84 & 0.80 \\
\hline $7 / 16-8 / 1$ & 4 & 5.6 & 3.9 & 313 & 113 & 210 & 73 & 0.65 \\
\hline $8 / 1-8 / 17$ & 6 & 12.7 & 9.4 & 759 & 285 & 520 & 182 & 1.56 \\
\hline 8/17-9/1 & 6 & 10.8 & 7.0 & 563 & 239 & 399 & 139 & 1.20 \\
\hline $9 / 1-9 / 16$ & 8 & 8.1 & 5.7 & 454 & 170 & 320 & 112 & 1.00 \\
\hline $9 / 16-9 / 23$ & 2 & 12.1 & 6.6 & 528 & 208 & 310 & 118 & 1.05 \\
\hline $9 / 23-10 / 10$ & 5 & 6.9 & 3.8 & 306 & 107 & 198 & 67 & 0.59 \\
\hline $10 / 10-10 / 27$ & 4 & 5.3 & 3.4 & 274 & 83 & 214 & 67 & 0.62 \\
\hline December & 2 & $<1.0(2)$ & 0.8 & 68 & 17 & $59(2)$ & $19(1)$ & $<0.04$ (2) \\
\hline January & 4 & $<1.0(2)$ & $<0.4$ (2) & $<33$ (2) & 14 & $13(3)$ & $<6(4)$ & $<0.04$ \\
\hline February & 2 & $<1.0$ & $<0.4$ (1) & $<33$ (1) & $<12(1)$ & $<10(2)$ & $<6(2)$ & $0.06(1)$ \\
\hline March & 1 & 8.2 & 0.4 & 34 & $<12$ (1) & $<10$ & $<6(1)$ & 0.27 \\
\hline \multicolumn{9}{|c|}{ Fine } \\
\hline $7 / 2-7 / 16$ & 8 & 13.2 & 0.9 & 69 & $45(2)$ & 44 & 11 & 0.32 \\
\hline $7 / 16-8 / 1$ & 4 & 6.2 & 0.5 & 39 & $<12(3)$ & 20 & 9 & 0.17 \\
\hline $8 / 1-8 / 17$ & 6 & 8.6 & 0.7 & 54 & $18(5)$ & 43 & 16 & 0.36 \\
\hline 8/17-9/1 & 6 & 10.6 & 2.1 & 166 & 42 & 197 & 44 & 0.55 \\
\hline $9 / 1-9 / 16$ & 8 & 11.8 & 2.4 & 190 & 80 & 163 & 51 & 0.58 \\
\hline $9 / 16-9 / 23$ & 2 & 36.5 & 2.1 & 166 & 67 & 273 & 30 & 0.65 \\
\hline $9 / 23-10 / 10$ & 5 & 9.3 & 1.6 & 130 & $42(1)$ & 77 & 23 & 0.41 \\
\hline $10 / 10-10 / 27$ & 4 & 4.7 & 1.5 & 120 & 43 & 107 & 29 & 0.39 \\
\hline December & 2 & $<1.0(2)$ & $<0.4$ (1) & $<33$ (1) & 15 & $<10$ (2) & $<6(2)$ & $<0.04$ (2) \\
\hline January & 4 & $<1.0(2)$ & $0.5(2)$ & $38(2)$ & $13(1)$ & $<10$ & $<6(3)$ & $<0.04$ (2) \\
\hline February & 2 & $<1.0$ & $0.4(1)$ & $33(1)$ & $<12$ (1) & $11(2)$ & $<6(1)$ & 0.04 \\
\hline March & 1 & 4.4 & 0.4 & 36 & 23 & 26 & 16 & 0.16 \\
\hline \multicolumn{9}{|c|}{ Total } \\
\hline $7 / 2-7 / 16$ & 8 & 22.4 & 5.7 & 459 & 225 & 298 & 95 & 1.12 \\
\hline $7 / 16-8 / 1$ & 4 & 11.8 & 4.4 & 352 & 121 & 229 & 82 & 0.82 \\
\hline $8 / 1-8 / 17$ & 6 & 21.2 & 10.1 & 813 & 303 & 562 & 198 & 1.92 \\
\hline 8/17-9/1 & 6 & 21.4 & 9.1 & 729 & 281 & 596 & 183 & 1.74 \\
\hline $9 / 1-9 / 16$ & 8 & 19.9 & 8.0 & 644 & 251 & 483 & 163 & 1.58 \\
\hline $9 / 16-9 / 23$ & 2 & 48.6 & 8.6 & 694 & 275 & 583 & 148 & 1.70 \\
\hline $9 / 23-10 / 10$ & 5 & 16.2 & 5.4 & 437 & 149 & 274 & 90 & 1.00 \\
\hline $10 / 10-10 / 27$ & 4 & 10.0 & 4.9 & 394 & 126 & 321 & 96 & 1.01 \\
\hline December & 2 & $<2.0$ & 1.2 & 99 & 32 & 64 & 22 & $<0.08$ \\
\hline January & 4 & $<2.0$ & $<0.8$ & $<66$ & 28 & $<20$ & $<12$ & 0.08 \\
\hline February & 2 & $<2.0$ & $<0.8$ & $<66$ & $<24$ & 21 & $<12$ & 0.10 \\
\hline March & 1 & 12.6 & 0.9 & 69 & 29 & 36 & 19 & 0.43 \\
\hline
\end{tabular}

${ }^{a}$ Data are aggregated biweekly and for periods of distinct PM characteristics, such as the Hidden Fire (16-23 September) and high dust periods (1-17 August). Date format is month/day. The number (n) of samples collected is given for each time period, while the number of samples below detection limit for each period is given in parentheses after the concentration value.

fraction. Enrichment factors with respect to $\mathrm{Al}\left(\mathrm{EF}_{\mathrm{X} / \mathrm{Al}}\right)$ were calculated as

$$
E F_{\frac{X}{A l}}=\frac{\left(\frac{X}{A l}\right)_{P M}}{\left(\frac{X}{A l}\right)_{\text {Crustal }}}
$$

where $(X / A l)_{\mathrm{PM}}$ is the mass ratio of an element $\mathrm{X}$ to $\mathrm{Al}$ in either the coarse or fine PM sample and $(X / A l)_{\text {crustal }}$ is the characteristic X/Al mass ratio of the average UCC value. Mean \pm SD of enrichment factors calculated for coarse aerosol fractions were $1.6 \pm 0.2,1.1 \pm 0.3,1.4 \pm 0.2$, and $3.1 \pm$ 0.5 for $\mathrm{Fe}, \mathrm{Ca}, \mathrm{Mg}$ and $\mathrm{V}$, respectively. Mean $\pm \mathrm{SD}$ of enrichment factors calculated for fine aerosol fractions were $1.9 \pm 1.1,0.9 \pm 0.6,1.4 \pm 0.4,6.0 \pm 2.6$ for $\mathrm{Fe}, \mathrm{Ca}, \mathrm{Mg}$ and $\mathrm{V}$, respectively. The enrichment factors in this study were generally not much higher than unity, indicating that these elements were mostly derived from crustal materials.

\subsection{Elemental Composition of Atmospheric Particles}

[17] Mean elemental concentrations for coarse, fine, and total atmospheric PM at the Lower Kaweah study site are presented in Table 1 for aggregated periods of the sampling campaign. While PM mass was typically concentrated in the fine fraction, the crustal elements measured in this study, $\mathrm{Al}$,

Table 2. Linear Relationships Between Dust Elements and $\mathrm{Al}^{\mathrm{a}}$

\begin{tabular}{lccc}
\hline & $\left(\mathrm{r}^{2}\right)$ & $\mathrm{m}$ & $\mathrm{EF}_{\mathrm{Al}}$ \\
\hline & & Coarse $(>1 \mu \mathrm{m})$ & \\
$\mathrm{Ca}$ & 0.82 & 0.38 & $1.1(0.3)$ \\
$\mathrm{Fe}$ & 0.99 & 0.69 & $1.6(0.2)$ \\
$\mathrm{Mg}$ & 0.98 & 0.24 & $1.4(0.2)$ \\
$\mathrm{V}$ & 0.98 & 0.0020 & $3.1(0.5)$ \\
& & Fine $(<1 \mu m)$ & \\
$\mathrm{Ca}$ & 0.53 & 0.36 & $0.9(0.6)$ \\
$\mathrm{Fe}$ & 0.57 & 1.13 & $1.9(1.1)$ \\
$\mathrm{Mg}$ & 0.89 & 0.26 & $6.0(2.4)$ \\
$\mathrm{V}$ & 0.75 & 0.0027 & 6.0 \\
\hline
\end{tabular}

${ }^{\mathrm{a}}$ Standard deviations are given in parentheses. All linear regression models are statistically significant $(p<0.01)$. Enrichment factors $\left(\mathrm{EF}_{\mathrm{Al}}\right.$ values) presented here have been calculated based on average UCC values [Taylor and McLennan, 1995]. 

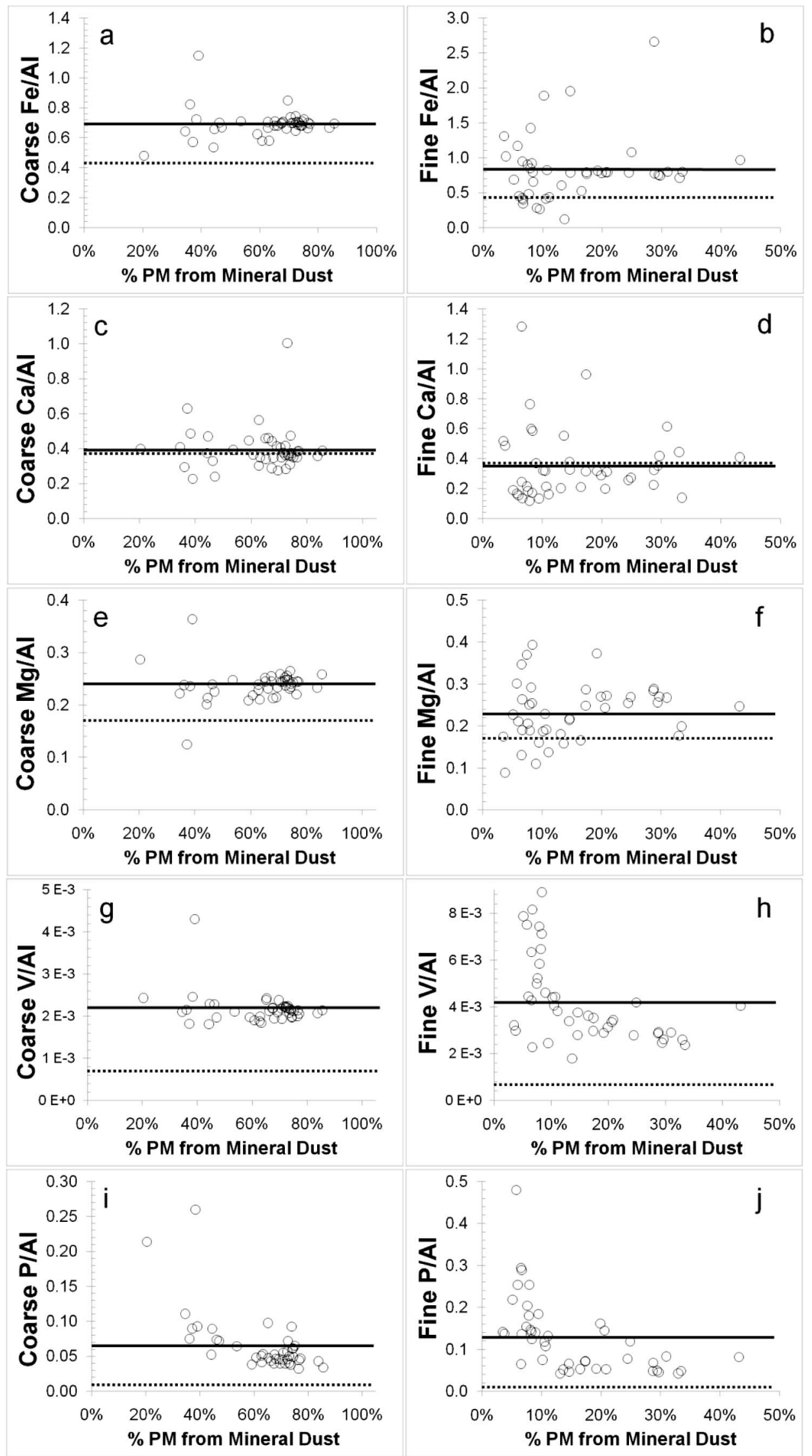

Figure 4 
$\mathrm{Ca}$, and $\mathrm{Mg}$, were consistently more abundant in the coarse PM fraction, reflecting their association with aeolian dust, which generally consists of particles greater than $1 \mu \mathrm{m}$ in diameter. Among detected elements, Al was most abundant, with a mean dry season concentration of 460 and $120 \mathrm{ng}$ $\mathrm{m}^{-3}$ in the coarse and fine fractions, respectively. $\mathrm{P}$ and $\mathrm{V}$ concentrations were also elevated in the coarse fraction, suggesting that they too were associated mostly with primary aerosol particles, although both of these elements had a considerable component $(\sim 30 \%)$ in the fine PM fraction.

[18] The elemental composition of atmospheric crustal material sampled at a particular location can be used to draw conclusions regarding the geographical sources of airborne dust [Hsu et al., 2008; Shen et al., 2006; Wu et al., 2009]. Particularly useful information can be obtained through analysis of the ratios of crustal elements, which are generally indicative of the dust source region and appear to be diagnostic for many sources [Holmes and Zoller, 1996; McKendry et al., 2001]. In this study, we have used a suite of crustal elements (i.e., $\mathrm{Al}, \mathrm{Fe}, \mathrm{Ca}$, and $\mathrm{Mg}$ ) and their mass ratios in order to characterize the dust present in the atmosphere at the Lower Kaweah site and to assess the relative contributions of different dust sources, including Asia.

3.3.1. Iron

[19] Dry season Fe concentrations in coarse and fine mode $\mathrm{PM}$ varied from 47 to $840 \mathrm{ng} \mathrm{m}^{-3}$ (mean $=457 \pm 228 \mathrm{ng}$ $\left.\mathrm{m}^{-3}\right)$ and $<33$ to $265 \mathrm{ng} \mathrm{m}^{-3}$ (mean $=119 \pm 72 \mathrm{ng} \mathrm{m}^{-3}$ ), respectively. Linear regression models $(y=m x+b)$ fit to $\mathrm{Fe}$ and $\mathrm{Al}$ in coarse particles (Table 2 ) reveal a characteristic $\mathrm{Fe} / \mathrm{Al}$ ratio $(\mathrm{m}=0.69)$ in the mineral dust over the sampling site, with a significant positive correlation $\left(\mathrm{r}^{2}=0.99\right)$ in the coarse PM fraction, reflecting the conservative atmospheric transport of these predominantly crustal elements. The temporal variability in the $\mathrm{Fe} / \mathrm{Al}$ ratio is very low in the coarse fraction (standard deviation $=0.095$ ), indicating that this is a characteristic relative abundance for atmospheric PM transported to the southern Sierra Nevada during the dry season. Mineral dust at the Lower Kaweah site is enriched in Fe relative to the average crustal concentration ratio of 0.43 [Taylor and McLennan, 1995], with $\mathrm{EF}_{\mathrm{Al}}$ values of 1.6 and 1.9 for coarse and fine $\mathrm{Fe}$, respectively. The mean $\mathrm{Fe} / \mathrm{Al}$ ratio found in our study fell between the characteristic $\mathrm{Fe} / \mathrm{Al}$ ratio for Asian dust (ranging from 0.78 to 0.62 moving from west to east across the Pacific Ocean) and measured values for agricultural dust within the San Joaquin Valley (0.47) [Holmes and Zoller, 1996; VanCuren and Cahill, 2002].

[20] Plotting the Fe/Al ratio against the percent contribution from mineral dust reveals that, in coarse PM samples with $\geq 50 \%$ mineral dust mass, the $\mathrm{Fe} / \mathrm{Al}$ ratio varied between 0.6 and 0.8 (Figure $4 a$ ). However, variability in the $\mathrm{Fe} / \mathrm{Al}$ ratio was greater in samples collected during local wildfires and during other periods when dust made $<50 \%$ contribution to the total particle load. Wider variability in the $\mathrm{Fe} / \mathrm{Al}$ ratio was observed for fine PM samples, signifying a greater relative importance of anthropogenic and combustion sources of atmospheric Fe to the fine PM fraction (Figure 4b) [Majestic et al., 2006]. However, almost all fine PM samples composed of $>20 \%$ mineral had Fe/Al ratios of $0.7-0.9$, which indicates a similar source for mineral dust for both coarse and fine PM fractions. Thus, the variability in $\mathrm{Fe} / \mathrm{Al}$ ratio indicates not only the varying contributions of two or more geologic sources of aeolian particles (i.e., Asian dust versus San Joaquin Valley dust), but also $\mathrm{Fe}$ derived from anthropogenic sources such as biomass burning and fossil fuel combustion [Guieu et al., 2005; Sholkovitz et al., 2009].

\subsubsection{Calcium and Magnesium}

[21] Globally, the abundances of $\mathrm{Ca}$ and $\mathrm{Mg}$ in crustal materials are represented as 3.0 and $1.3 \%$, respectively [Taylor and McLennan, 1995]. These elements are present in dust aerosol particles in association with carbonate minerals, such as calcite and dolomite, which are particularly abundant in atmospheric dust generated from source regions dominated by sedimentary parent materials. Dry season $\mathrm{Ca}$ concentrations in coarse and fine PM samples varied from $<12$ to $382 \mathrm{ng} \mathrm{m}^{-3}$ (mean $=180 \pm 100 \mathrm{ng} \mathrm{m}^{-3}$ ) and $<12$ to $179 \mathrm{ng} \mathrm{m}^{-3}$ (mean $=49 \pm 38 \mathrm{ng} \mathrm{m}^{-3}$ ), respectively (Table 1). $\mathrm{Mg}$ concentrations ranged from 13 to $205 \mathrm{ng} \mathrm{m}^{-3}$ (mean $\left.=108 \pm 55 \mathrm{ng} \mathrm{m}^{-3}\right)$ and $<6$ to $70 \mathrm{ng} \mathrm{m}^{-3}$ $\left(\right.$ mean $=28 \pm 20 \mathrm{ng} \mathrm{m}^{-3}$ ) for coarse and fine PM samples, respectively. For both $\mathrm{Ca}$ and $\mathrm{Mg}$, mass abundance in the coarse PM fraction was strongly correlated with $\mathrm{Al}\left(\mathrm{r}^{2}=0.82\right.$ for $\mathrm{Ca}$ and 0.98 for $\mathrm{Mg}$ ), with a weaker correlation observed for the fine PM fraction $\left(\mathrm{r}^{2}=0.53\right.$ for $\mathrm{Ca}$ and 0.89 for $\mathrm{Mg}$ ). The mean $\mathrm{Ca} / \mathrm{Al}$ ratios obtained in this study are very close to the average value for upper continental crust, with EF values very close to 1 in both size fractions (Table 2). This observation suggests that carbonate minerals in the mineral dust sampled at the Lower Kaweah site may be somewhat less abundant than aluminosilicates, as carbonate-rich dust would be expected to have a higher EF value. PM samples also exhibited $\mathrm{Mg} / \mathrm{Al}$ ratios that were only slightly enriched above the crustal average, evidence further supporting the relative scarcity of carbonates in Sierra Nevada aerosols. Similar to the trend observed for $\mathrm{Fe}$, more scatter of $\mathrm{Ca} / \mathrm{Al}$ and $\mathrm{Mg} / \mathrm{Al}$ ratios were observed in the fine fraction (Figures $4 \mathrm{~d}$ and $4 \mathrm{f}$ ), particularly in samples with a low abundance of dust, while the ratios for the coarse PM mode had a narrower range (Figures $4 \mathrm{c}$ and $4 \mathrm{e}$ ), due to the significantly higher contribution from mineral dust to the coarse fraction.

\subsubsection{Vanadium}

[22] On average, the upper continental crust contains $60 \mathrm{ppm} \mathrm{V}$ yielding a V/Al ratio of about 0.0007 [Taylor and McLennan, 1995]; however, atmospheric V is not considered to be a predominantly crustal element, but is often used as a diagnostic tracer for the atmospheric products of fossil fuel (particularly oil) combustion [Moreno et al., 2008]. For example, Sholkovitz et al. [2009] developed a positive linear relationship between V/Al ratios and the percent solubility of aerosol $\mathrm{Fe}$ and, using this relationship as a tracer for anthropogenic aerosols, estimated the extent of soluble $\mathrm{Fe}$ deposition to the North Atlantic resulting from oil combustion. At Lower Kaweah, a strong correlation between $\mathrm{Al}$ and $\mathrm{V}$ was observed in both size fractions (Table $2, \mathrm{r}^{2}=0.98$ and

Figure 4. (a-j) Scatterplots of coarse and fine elemental ratios to Al plotted against the relative contribution from mineral dust (based on Al mass concentration) to total PM. The mean crustal ratios for the study period are displayed as solid lines. Average crustal ratios (dashed lines) were obtained from Taylor and McLennan [1995]. 
Table 3. Mean Elemental Mass Ratios Measured in PM Samples From the Lower Kaweah Site, Along With Elemental Ratios of Various Dust Source Profiles Representing Regional (San Joaquin) and Distant (Asian) Sources of Airborne Dust ${ }^{\mathrm{a}}$

\begin{tabular}{|c|c|c|c|c|c|c|c|}
\hline Sample Type & $\mathrm{Fe} / \mathrm{Al}$ & $\mathrm{Ca} / \mathrm{Al}$ & $\mathrm{Mg} / \mathrm{Al}$ & $\mathrm{V} / \mathrm{Al}$ & $\mathrm{P} / \mathrm{Al}$ & $\mathrm{Fe} / \mathrm{Ca}$ & Source \\
\hline \multicolumn{8}{|l|}{ Lower Kaweah } \\
\hline Coarse $(>1 \mu \mathrm{m})$ & $0.69(0.10)$ & $0.39(0.12)$ & $0.24(0.03)$ & $0.0022(0.0004)$ & $0.065(0.043)$ & $1.89(0.68)$ & Present study \\
\hline Fine $(<1 \mu \mathrm{m})$ & $0.83(0.47)$ & $0.35(0.23)$ & $0.23(0.07)$ & $0.0042(0.0018)$ & $0.126(0.089)$ & $3.01(2.15)$ & Present study \\
\hline "High dust" $(>1 \mu \mathrm{m})$ & $0.69(0.01)$ & $0.38(0.01)$ & $0.24(0.01)$ & $0.0021(0.0001)$ & $0.044(0.006)$ & $1.81(0.03)$ & Present study \\
\hline Asian dust (Hawaii) & 0.75 & 1.00 & 0.42 & 0.0040 & 0.046 & 1.10 & Holmes and Zoller [1996] \\
\hline Asian dust (China) & 0.78 & 0.76 & 0.19 & 0.0050 & 0.046 & 1.04 & Shen et al. [2006] \\
\hline Asian dust (California) & 0.62 & 0.44 & 0.46 & 0.0047 & - & 1.41 & VanCuren et al. [2005] \\
\hline \multicolumn{8}{|l|}{ San Joaquin dust } \\
\hline Agricultural dust & 0.47 & 0.22 & 0.07 & 0.0006 & 0.009 & 2.10 & Chow et al. [2003] \\
\hline Unpaved roads & 0.54 & 0.44 & 0.09 & 0.0010 & 0.008 & 1.22 & Chow et al. [2003] \\
\hline Paved roads & 0.52 & 0.35 & 0.08 & 0.0005 & 0.039 & 1.50 & Chow et al. [2003] \\
\hline Average UCC ratio & 0.43 & 0.37 & 0.17 & 0.0007 & 0.009 & 1.20 & Taylor and McLennan [1995] \\
\hline
\end{tabular}

${ }^{a}$ Standard deviations for the elemental ratios determined in the present study are given in parentheses.

0.75 for coarse and fine PM, respectively), suggesting that atmospheric $\mathrm{V}$ in the Sierra Nevada is primarily associated with mineral dust. The mean $\mathrm{V} / \mathrm{Al}$ ratio was 0.0022 and 0.0042 for coarse and fine PM, respectively. These values are similar to those observed in atmospheric dust from North Africa [Eglinton et al., 2002] and Asia [Holmes and Zoller, 1996], but exceed the crustal average of 0.0007 , with $\mathrm{EF}_{\mathrm{Al}}$ values of 3.1 and 6 for coarse and fine PM, respectively. As with $\mathrm{Fe}$, more scatter of $\mathrm{V} / \mathrm{Al}$ ratio values were observed in the fine fraction (0.0018-0.0089) compared to the coarse fraction, while V/Al ratios exhibited an extremely narrow range (0.0018-0.0024) in the coarse PM mode and consistently reached a minimum in samples with a large relative proportion of dust (Figure $4 \mathrm{~g}$ ). The higher $\mathrm{V} / \mathrm{Al}$ ratio (and lower correlation with $\mathrm{Al}$ ) observed in the fine mode PM samples suggests that $\mathrm{V}$ from anthropogenic emissions is a more important source for fine accumulation mode particles. However, based on mixing calculations performed using 0.0018 for the crustal V/Al ratio (which is likely to be a more appropriate estimate for atmospheric crustal material at the Lower Kaweah site based on arguments presented above), we contend that atmospheric dust was the largest source of atmospheric $\mathrm{V}$ loading to the Lower Kaweah site during the sampling period, representing on average 85 and $50 \%$ of coarse and fine mode $\mathrm{V}$, respectively. This result is similar to those obtained at a high-elevation site reported by Marenco et al. [2006].

\subsubsection{Phosphorus}

[23] Atmospheric TP concentrations during the dry season ranged from 9 to $47 \mathrm{ng} \mathrm{m}^{-3}$ (mean $=24 \pm 10 \mathrm{ng} \mathrm{m}^{-3}$ ) and 2 to $28 \mathrm{ng} \mathrm{m}^{-3}$ (mean $=11 \pm 6 \mathrm{ng} \mathrm{m}^{-3}$ ) for coarse and fine particles, respectively. Such values are nearly an order of magnitude higher than those observed in other locations of the Sierra Nevada [Mahowald et al., 2008], although they are similar to $\mathrm{P}$ measurements made in the Lake Tahoe basin [Zhang et al., 2002], the Mediterranean region [Bergametti et al., 1992; Markaki et al., 2003; Migon et al., 2001] and Brazil [Artaxo et al., 2002; Fuzzi et al., 2007]. Atmospheric $\mathrm{P}$ is thought to be associated primarily with mineral dust [Graham and Duce, 1979; Mahowald et al., 2008], particularly at high-elevation sites [Morales-Baquero et al., 2006], and this assertion is generally supported by the observations made in our study. Scatterplots of the P/Al ratio in coarse and fine PM (Figures $4 \mathrm{i}$ and $4 \mathrm{j}$ ) reveal a characteristic $\mathrm{P} / \mathrm{Al}$ ratio in the mineral dust sampled during this study. In the majority of coarse PM samples consisting of $50 \%$ or more mineral material, the $\mathrm{P} / \mathrm{Al}$ ratio varied between 0.03 and 0.08 . In contrast, a much wider variability in $\mathrm{P} / \mathrm{Al}$ ratio was observed in fine PM samples and is most likely the result of lower abundance of dust in the fine fraction and the relatively greater importance of anthropogenic sources of atmospheric $\mathrm{P}$ in the fine aerosol mode [Markaki et al., 2003]. However, fine PM samples composed of $20 \%$ or more mineral dust still exhibit a range of $\mathrm{P} / \mathrm{Al}$ ratios $(0.04-$ 0.12) similar to the coarse PM samples.

\section{Discussion}

\subsection{Regional Versus Global Sources of Dust to the Sierra Nevada}

[24] The elemental ratios for samples collected in the present study have been separated by fine and coarse PM in order to directly compare means and standard deviations between size fractions (Table 3). Furthermore, we have separated out the coarse PM samples collected during the period 1-17 August 2008 when mineral dust represented approximately $75 \%$ of the total coarse PM mass (Table 1), and designated them "high dust" samples. Uniformly low standard deviations for elemental ratios in the high dust samples indicate that this is a very well constrained elemental profile. Although the comparison of elemental ratios cannot be used to provide precise estimates for different dust sources, they can be used in a semiquantitative fashion to better understand potential dust sources to the Sierra Nevada.

[25] The average $\mathrm{Fe} / \mathrm{Al}$ ratio of Asian dust has been reported as 0.75 in previous studies [Holmes and Zoller, 1996; Shen et al., 2006] and this value is similar to those obtained in our study (0.69 for coarse and high dust samples; Table 3). In comparison, San Joaquin dust profiles determined by Chow et al. [2003] exhibit lower Fe/Al ratios $(0.47-0.54)$ that are closer to the average values for the upper continental crust (UCC) determined by Taylor and McLennan [1995]. Conversely, the $\mathrm{Ca} / \mathrm{Al}$ and $\mathrm{Mg} / \mathrm{Al}$ ratios measured in our study indicate that $\mathrm{Ca}$ and $\mathrm{Mg}$ are enriched only a little above their UCC values $(0.37$ and 0.17 , respectively) and fall between the overlapping values for San Joaquin dust and Asian dust. Asian dust typically displays higher $\mathrm{Ca} / \mathrm{Al}$ and $\mathrm{Mg} / \mathrm{Al}$ ratios than the $\mathrm{UCC}$ [Holmes and Zoller, 1996; Shen et al., 2006]; however, 


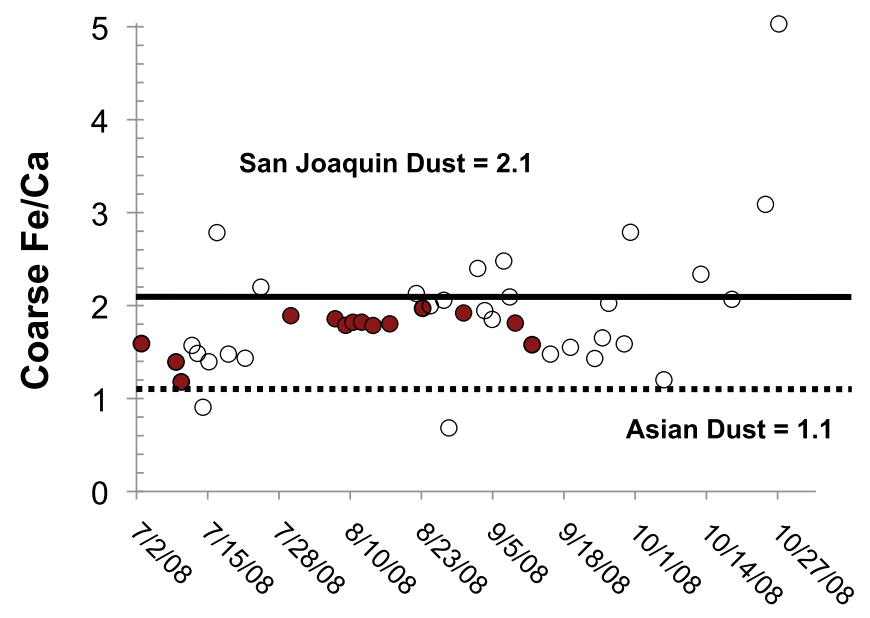

Figure 5. Temporal variability in the $\mathrm{Fe} / \mathrm{Ca}$ mass ratio of coarse PM samples collected at the Lower Kaweah site showing the significant increase over background levels in October. Samples characterized by high mineral dust loading $\left(>7 \mu \mathrm{g} \mathrm{m}^{-3}\right)$ are indicated with solid dots.

VanCuren and Cahill [2002] report $\mathrm{Ca} / \mathrm{Al}$ and $\mathrm{Mg} / \mathrm{Al}$ values for Asian dust detected at a high-elevation site in the western U.S. that are lower than those of dust sampled in China and Hawaii and more similar to those observed for Lower Kaweah samples in this study. Furthermore, there is evidence that atmospheric processing of Asian dust can occur during long-range transport which results in the deliquescence and consequent depletion of $\mathrm{Ca}$ from the mineral aerosol load through reactions between calcium carbonate and acidic species associated with the Asian continental plume [Krueger et al., 2003].

[26] Modeling studies by VanCuren et al. [2005] suggest that the $\mathrm{Fe} / \mathrm{Ca}$ ratio is the most appropriate diagnostic tracer for Asian dust in North America. They used Fe/Ca mass ratios of atmospheric PM samples collected at various highelevation sites in California to differentiate mineral aerosol of Asian origin $(\mathrm{Fe} / \mathrm{Ca}=1.1)$ from locally generated dust particles. The $\mathrm{Fe} / \mathrm{Ca}$ ratios measured in our study ranged from $0.69-5.03($ mean $=1.89 \pm 0.68)$ and $1.78-1.86($ mean $=$ $1.81 \pm 0.03$ ) for coarse and high dust samples, respectively. These mean ratios are comparable to $\mathrm{Fe} / \mathrm{Ca}$ ratios that have been measured in San Joaquin agricultural dust (2.1; Table 3), suggesting that regional agricultural activities are a quantitatively significant source of atmospheric PM loading to the Sierra Nevada. However, the remarkably low $\mathrm{Ca} / \mathrm{Al}$ ratios observed in the Lower Kaweah samples suggest that atmospheric processing of calcium carbonate dust may be an important factor and one that may produce artificially high $\mathrm{Fe} / \mathrm{Ca}$ ratios through depletion of $\mathrm{Ca}$ in the coarse aerosol mode. The strong agreement in mean $\mathrm{Fe} / \mathrm{Ca}$ values between total coarse PM and high dust samples (and the low standard deviation in $\mathrm{Fe} / \mathrm{Ca}$ observed for the high dust samples) suggest that the ratio measured in this study is a characteristic ratio for atmospheric mineral dust transported to the southern Sierra Nevada. Fe/Ca ratios in atmospheric PM sampled at the Lower Kaweah site showed a significant upward trend during the period of July to early September and were observed to increase considerably near the beginning of October (Figure 5), concurrent with the end of
Asian dust transport season (March-November [VanCuren, 2003]). These temporal trends in the $\mathrm{Fe} / \mathrm{Ca}$ ratio suggest an overall decrease in the contribution of Asian dust sources over the course of the dry season. We speculate that the Hidden Fire caused the temporary decline in the Fe/Ca ratio in September. Nearly all of the atmospheric mineral PM sampled in our study exhibited an $\mathrm{Fe} / \mathrm{Ca}$ ratio higher than the characteristic Asian $\mathrm{Fe} / \mathrm{Ca}$ ratio $(\sim 1.1)$, but we did, however, observe $\mathrm{Fe} / \mathrm{Ca}$ values in the early part of the summer that were significantly reduced below the characteristic San Joaquin agricultural dust $\mathrm{Fe} / \mathrm{Ca}$ ratio $(\sim 2.1)$, and we propose that this was primarily due to inputs of Asian dust. This hypothesis is supported by 11 day AMBT data (Figure 2b) and particle size-resolved mass distribution data for the Lower Kaweah site reported by Vicars et al. [2010], which showed that primary aerosol particle mass at the site was enriched in the 1.0-3.2 $\mu \mathrm{m}$ size range during the sampling period, which encompasses the typical size distribution of Asian dust particles observed in North America [McKendry et al., 2001; VanCuren and Cahill, 2002]. However, it should be noted that Asian dust transport is typically expected to peak in spring (March-May) and thus this study may be missing the most significant annual contributions from Asian sources.

[27] In order to provide a quantitative estimate of fractional contributions from Asian dust sources, we have performed two-component mixing calculations using the coarse $\mathrm{PM} \mathrm{Fe} / \mathrm{Ca}$ ratios shown in Figure 5 (Figure 6). However, due to variations in the $\mathrm{Fe} / \mathrm{Ca}$ ratio caused by significant inputs of nondust PM (e.g., the Hidden Fire period), we restricted the mixing computations to samples with relatively large amounts of dust loading $\left(>7 \mu \mathrm{g} \mathrm{m}^{-3}\right.$, solid dots in Figure 5). Additionally, because the mixture analysis depends on measurements of $\mathrm{Fe}$ and $\mathrm{Ca}$ performed in our study and estimates of characteristic $\mathrm{Fe} / \mathrm{Ca}$ ratios in the Asian and local end-members, the computed contributions

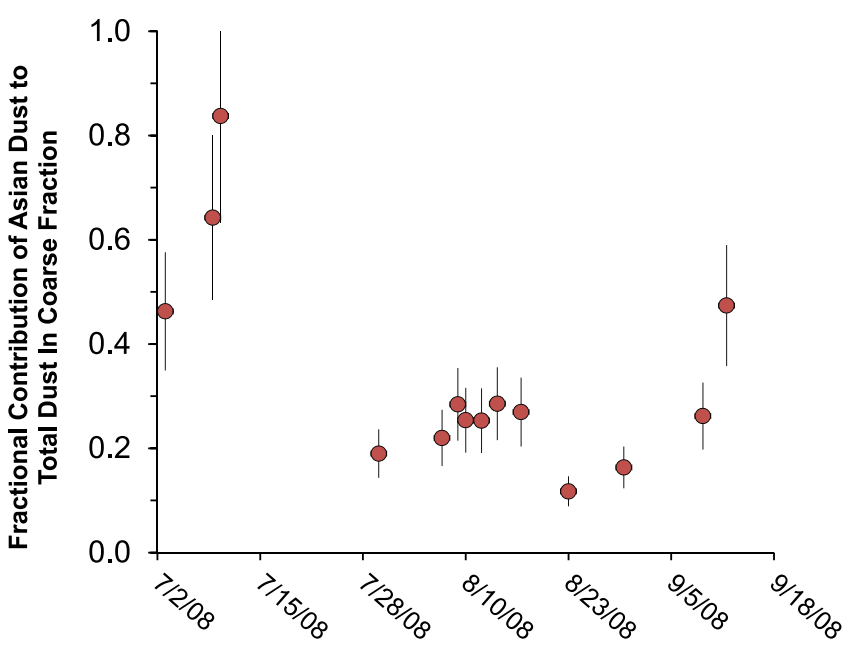

Figure 6. Fractional contribution of Asian dust sources to total dust in the coarse aerosol fraction computed from a two-component mixing model incorporating Asian and San Joaquin Valley dust end-members. Data shown are from samples characterized by high mineral dust loading $\left(>7 \mu \mathrm{g} \mathrm{m}^{-3}\right)$. Error bars denote the $95 \%$ confidence interval for the Asian dust contribution. 

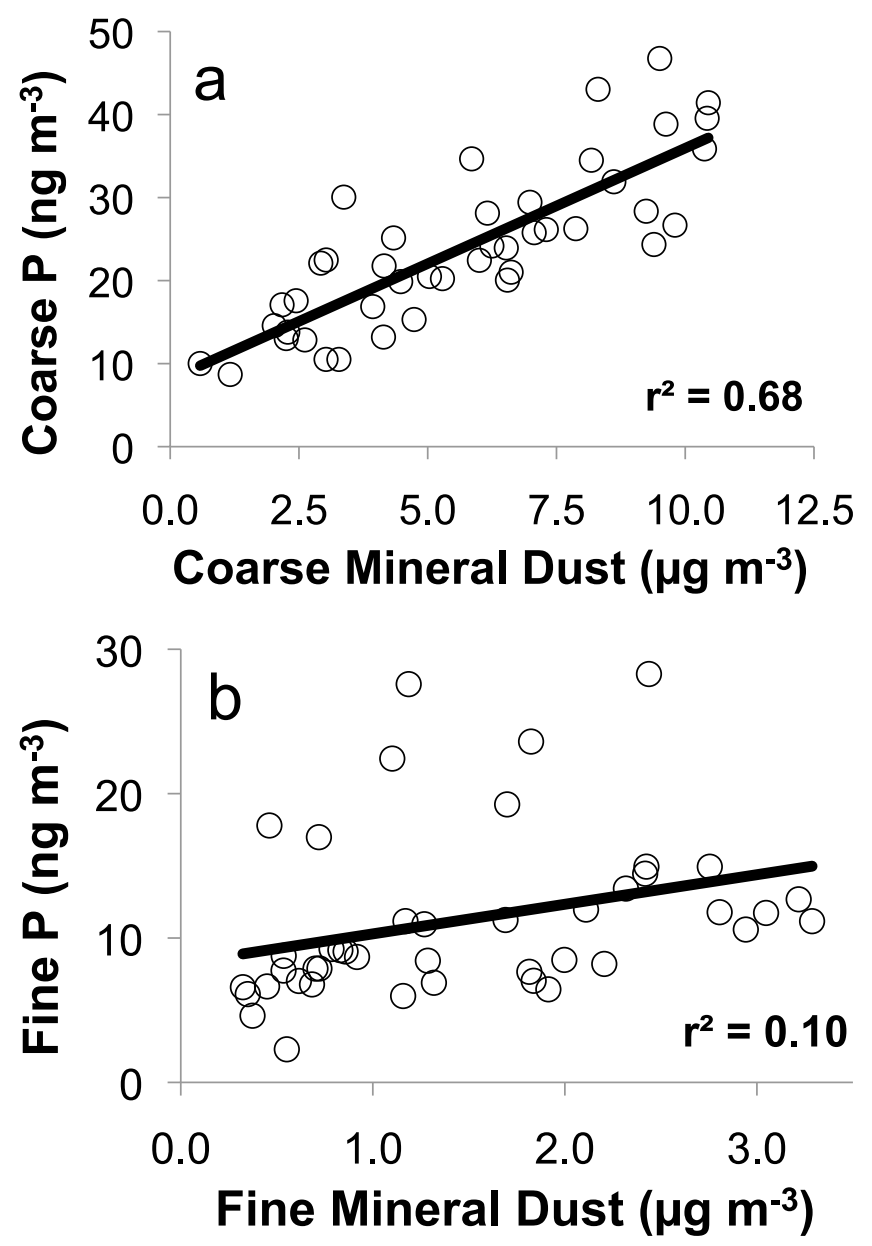

Figure 7. Linear regression analysis showing the significant positive correlation exhibited between (a) coarse atmospheric TP and mineral dust concentration. (b) This correlation was much weaker in fine PM samples.

from Asian dust have significant uncertainty. To provide an estimate of this uncertainty we used propagation of error techniques incorporating errors in $\mathrm{Fe}$ and $\mathrm{Ca}$ analyses of Sierra Nevada samples and estimated uncertainties in characteristic $\mathrm{Fe} / \mathrm{Ca}$ ratios in the two end-members to compute the 95\% confidence interval around the Asian dust contribution values (vertical area bars in Figure 6). For these samples, the fractional contributions from Asian sources to total dust loading vary between 0.4 and 0.9 (i.e., 40-90\%) during early July. In August and September the fractional contributions from Asian sources varied between 0.1 and 0.3 with the exception of the 12 September sample where $\mathrm{f}_{\text {Asian }}=0.47$. From the mixture analysis we speculate that the Asian dust source is strongest in early summer, when summertime trans-Pacific air mass transport was most active, whereas in the late summer and early fall, transPacific sources were overwhelmed by regional dust sources (e.g., agricultural activities in the San Joaquin Valley and forest fires).

4.2. Implications of Dust Loading to the Sierra Nevada

[28] Results of this study indicate that the atmospheric $\mathrm{P}$ content over the Sierra Nevada is significantly correlated with mineral dust loading (Figure $7 \mathrm{a}, \mathrm{r}^{2}=0.69, \mathrm{p}<0.0001$ ), suggesting that aeolian transport is a significant source of this important nutrient. The relative contribution of mineral sources to the total atmospheric P load over the Lower Kaweah site can be calculated through the use of enrichment factors $\left(E F_{\mathrm{P} / \mathrm{Al}}\right.$ from equation (2)), $\mathrm{P}$ concentrations in dust $\left[(P)_{\mathrm{PM}}\right]$ and the following relationship:

$$
\frac{(P)_{D u s t}}{(P)_{P M}}=\frac{1}{E F_{\frac{P}{A}}}
$$

[29] Equation (3) computes the ratio of $\mathrm{P}$ in mineral dust to total atmospheric P loading; however, an accurate estimation of $(\mathrm{P})_{\text {Dust }} /(\mathrm{P})_{\mathrm{PM}}$ is dependent on the selection of an appropriate value for $(\mathrm{P} / \mathrm{Al})_{\text {crustal reference }}$ in the calculation of $E F_{\mathrm{P} / \mathrm{Al}}$ using equation (2). The $\mathrm{P} / \mathrm{Al}$ ratio in soils and atmospheric mineral dust is difficult to define precisely due to the heterogeneous elemental composition of soils and erodible rocks in different regions of the world. Current best estimates for the P/Al ratio of crustal material and mineral dust vary from the UCC average of 0.009 [Taylor and McLennan, 1995], to 0.013 for Saharan dust [Guieu et al., 2002], 0.030 for apatite-rich dust derived from arid North African soils [Bergametti et al., 1992], and 0.046 for Asian dust [Holmes and Zoller, 1996]. In the present study, the P/Al ratio of our high dust samples (Table 3) was found to be relatively well constrained, with a mean value and standard deviation of $0.044 \pm 0.006$. In order to obtain a first-order approximation of the fractional contribution from mineral dust to atmospheric P loading, we have adopted a value of 0.035 for $(\mathrm{P} / \mathrm{Al})_{\text {dust }}$, which was the lowest $\mathrm{P} / \mathrm{Al}$ value observed during the high dust period at Lower Kaweah. Use of this $\mathrm{P} / \mathrm{Al}$ value enabled us to calculate $\mathrm{EF}_{\mathrm{P} / \mathrm{Al}}$ for each sampling period and the relative significance of dustassociated $\mathrm{P}$ was assessed. From inspection of Figures $8 \mathrm{a}$ and $8 \mathrm{~b}$, it is evident that mineral dust is an important source of atmospheric $\mathrm{P}$ at Lower Kaweah, typically representing $40-75 \%$ and $20-60 \%$ of total coarse and fine atmospheric $\mathrm{P}$, respectively. Predictably, dust contributions to total coarse atmospheric $\mathrm{P}$ were particularly relevant $(\sim 75 \%)$ during the high dust period (1-17 August). However, mineral dust contributes very little $\mathrm{P}$ to the submicron particle range for most of July and August, although it comprises approximately $40-60 \%$ of fine mode PM in September and October.

\section{Conclusions}

[30] Based on a 4 month, high-intensity record of sizesegregated PM samples collected from a high-elevation site, this study represents the first comprehensive data set characterizing the elemental composition and temporal variability of mineral dust and associated atmospheric $\mathrm{P}$ over the Sierra Nevada, California during the summer growing season. Results presented here add to our understanding of the nature and magnitude of aeolian transport to high-elevation sites of the western U.S. whose hydrology and ecology may be sensitive to dust input [Neff et al., 2008].

[31] The mass concentration of coarse $(>1 \mu \mathrm{m}$ diameter $)$ atmospheric PM in the southern Sierra Nevada, California was dominated by a temporally consistent contribution from mineral dust (50-80\%) throughout the study period. Conversely, fine mode PM typically contained a lesser propor- 

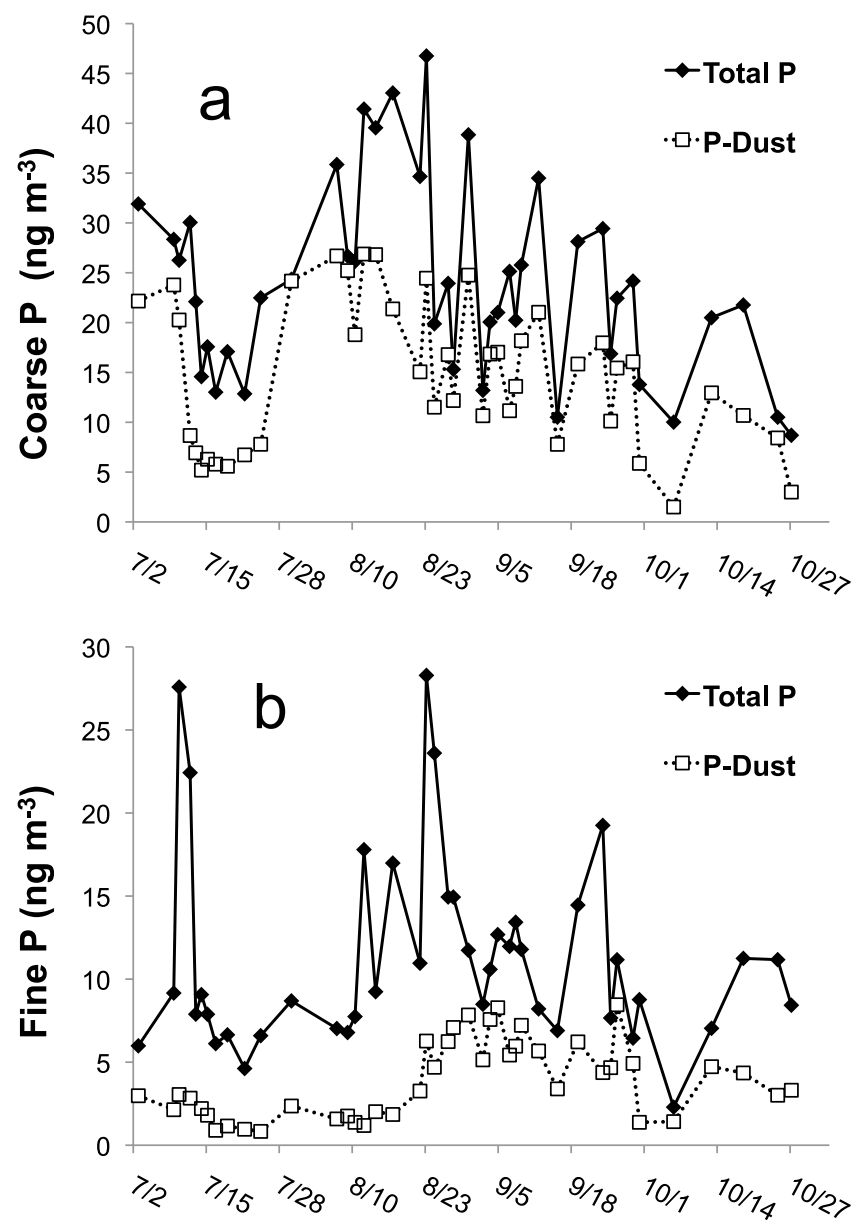

Figure 8. Temporal variability in total $\mathrm{P}$ and estimated $\mathrm{P}$ dust concentrations for (a) coarse and (b) fine filter samples.

tion of mineral dust $(7-33 \%)$, and exhibited greater elemental enrichments relative to crustal averages (particularly for $\mathrm{Fe}, \mathrm{V}$, and $\mathrm{P}$ ), reflecting the importance of anthropogenic sources in influencing the chemical composition of the fine mode PM transported to the region.

[32] Total phosphorus concentrations were significantly correlated $\left(\mathrm{r}^{2}=0.68\right)$ with the mass of atmospheric dust. A characteristic $\mathrm{P} / \mathrm{Al}$ ratio was observed in the coarse fraction during periods of high dust loading, and this ratio was used to estimate the relative contribution from mineral dust to total atmospheric P. Mineral dust was found to be the predominant source of atmospheric $P$ in the Sierra Nevada, with a fractional contribution ranging from $40-75 \%$ and $20-60 \%$ for coarse and fine atmospheric PM fractions, respectively.

[33] The mass concentrations of crustal elements (Fe, Ca, $\mathrm{Mg}$ ) in the coarse PM fraction were significantly correlated with Al throughout the study period and coarse PM exhibited elemental ratios that were temporally consistent and distinguishable from those of other sites. $\mathrm{Fe} / \mathrm{Al}$ and $\mathrm{Fe} / \mathrm{Ca}$ ratios of samples collected at our sampling site suggest a mixture of mineral dust from regional agricultural activities and long-range transport of mineral dust from Asia, with the regional sources playing their most significant role in the late summer and early fall. The occurrence of trans-Pacific transport during the sampling period was confirmed by AMBT analysis (for example; Figure 2b); the concentration of coarse particle mass in the $1.0-3.2 \mu \mathrm{m}$ size range [Vicars et al., 2010] provides additional evidence for long-range transport, as this is the typical size distribution of Asian dust observed in North America. The transport of aeolian material from Asia may be a particularly important factor determining atmospheric TP concentrations in the Sierra Nevada; particles in the $1.0-3.2 \mu \mathrm{m}$ size range contributed between 40 and $70 \%$ of TP throughout the sampling period.

[34] Acknowledgments. The authors would like to thank the Air Resources Division of Sequoia and Kings Canyon National Park, particularly Annie Esperanza and Heather Veerkamp-Tobin, for their help with experimental design and data collection. Stacked Filter Unit components and technical advice regarding ambient particulate matter sampling were graciously provided by Thomas Cahill and David Barnes of UC Davis, DELTA Group. We would also like to thank Delores Lucero and Kristine Richardson of UC Riverside for their support in the field and help with chemical analysis. The authors gratefully acknowledge the NOAA Air Resources Laboratory for the provision of the HYSPLIT transport and dispersion model and READY website (http://www.arl.noaa.gov/ready.php) used in this publication. Comments from anonymous reviewers significantly improved the manuscript. This work was funded by the National Science Foundation, Long-Term Research in Environmental Biology program (award 0614207).

\section{References}

Arimoto, R., R. A. Duce, B. J. Ray, W. G. Ellis Jr., J. D. Cullen, and J. T. Merrill (1995), Trace elements in the atmosphere over the North Atlantic, J. Geophys. Res., 100, 1199-1213, doi:10.1029/94JD02618.

Artaxo, P., J. V. Martins, M. A. Yamasoe, A. S. Procópio, T. M. Pauliquevis, M. O. Andreae, P. Guyon, L. V. Gatti, and A. M. C. Leal (2002), Physical and chemical properties of aerosols in the wet and dry seasons in Rondônia, Amazonia, J. Geophys. Res., 107(D20), 8081, doi:10.1029/ 2001JD000666.

Bergametti, G., L. Gomes, G. Coude-Gaussen, P. Rognon, and M.-N. Le Coustumer (1989), African dust observed over Canary Islands: Sourceregions identification and transport pattern for some summer situations, J. Geophys. Res., 94, 14,855-14,864, doi:10.1029/JD094iD12p14855.

Bergametti, G., E. Remoudaki, R. Losno, E. Steiner, B. Chatenet, and P. Buatmenard (1992), Source, transport, and deposition of atmospheric phosphorus over the northwestern Mediterranean, J. Atmos. Chem., 14, 501-513, doi:10.1007/BF00115254.

Bishop, J. K. B., R. E. Davis, and J. T. Sherman (2002), Robotic observations of dust storm enhancement of carbon biomass in the North Pacific, Science, 298, 817-821, doi:10.1126/science.1074961.

Bytnerowicz, A., M. Tausz, R. Alonso, D. Jones, R. Johnson, and N. Grulke (2002), Summer-time distribution of air pollutants in Sequoia National Park, California, Environ. Pollut., 118, 187-203, doi:10.1016/S02697491(01)00312-8.

Carroll, J. J., and A. J. Dixon (2002), Regional scale transport over complex terrain, a case study: Tracing the Sacramento plume in the Sierra Nevada of California, Atmos. Environ., 36, 3745-3758, doi:10.1016/S13522310(02)00305-9.

Chadwick, O. A., L. A. Derry, P. M. Vitousek, B. J. Huebert, and L. O. Hedin (1999), Changing sources of nutrients during four million years of ecosystem development, Nature, 397, 491-497, doi:10.1038/17276.

Chen, H.-Y., T.-H. Fang, M. R. Preston, and S. Lin (2006), Characterization of phosphorus in the aerosol of a coastal atmosphere: Using a sequential extraction method, Atmos. Environ., 40, 279-289.

Chow, J. C., J. G. Watson, L. L. Ashbaugh, and K. L. Magliano (2003), Similarities and differences in PM10 chemical source profiles for geological dust from the San Joaquin Valley, California, Atmos. Environ., 37, 1317-1340.

Cutten, D. R., M. A. Jarzembski, V. Srivastava, R. F. Pueschel, S. D. Howard, and E. W. McCaul Jr. (2003), Boundary layer aerosol composition over Sierra Nevada Mountains using 9.11- and 10.59- $\mu \mathrm{m}$ continuous wave lidars and modeled backscatter from size distribution data, J. Geophys. Res., 108(D3), 4129, doi:10.1029/2002JD002252.

Draxier, R. R., and G. D. Hess (1998), An overview of the HYSPLIT 4 modeling system for trajectories, dispersion and deposition, Aust. Meteorol. Mag., 47, 295-308

Eglinton, T. I., G. Eglinton, L. Dupont, E. R. Sholkovitz, D. Montluçon, and C. M. Reddy (2002), Composition, age, and provenance of organic matter in NW African dust over the Atlantic Ocean, Geochem. Geophys. Geosyst., 3(8), 1050, doi:10.1029/2001GC000269. 
Ewell, D. M., R. G. Flocchini, L. O. Myrup, and T. A. Cahill (1989), Aerosol transport in the southern Sierra Nevada, J. Appl. Meteorol., 28, 112-125, doi:10.1175/1520-0450(1989)028<0112:ATITSS $>2.0 . \mathrm{CO} ; 2$.

Fenn, M. E., et al. (2003), Ecological effects of nitrogen deposition in the western United States, BioScience, 53, 404-420, doi:10.1641/0006-3568 (2003)053[0404:EEONDI]2.0.CO;2.

Freitas, M. C., S. M. Almeida, M. A. Reis, and M. G. Ventura (2004), Neutron activation analysis: Still a reference method for air particulate matter measurements, J. Radioanal. Nucl. Chem., 262, 235-239, doi:10.1023/B JRNC.0000040880.76829.0d.

Fuzzi, S., et al. (2007), Overview of the inorganic and organic composition of size-segregated aerosol in Rondônia, Brazil, from the biomass-burning period to the onset of the wet season, J. Geophys. Res., 112, D01201, doi:10.1029/2005JD006741.

Graham, W. F., and R. A. Duce (1979), Atmospheric pathways of the phosphorus cycle, Geochim. Cosmochim. Acta, 43, 1195-1208, doi:10.1016/ 0016-7037(79)90112-1.

Graham, W. F., and R. A. Duce (1982), The atmospheric transport of phosphorus to the western North-Atlantic, Atmos. Environ., 16, 1089-1097, doi:10.1016/0004-6981(82)90198-6.

Guieu, C., M.-D. Loÿe-Pilot, C. Ridame, and C. Thomas (2002), Chemical characterization of the Saharan dust end-member: Some biogeochemical implications for the western Mediterranean Sea, J. Geophys. Res., 107(D15), 4258, doi:10.1029/2001JD000582.

Guieu, C., S. Bonnet, T. Wagener, and M.-D. Loÿe-Pilot (2005), Biomass burning as a source of dissolved iron to the open ocean?, Geophys. Res. Lett., 32, L19608, doi:10.1029/2005GL022962.

Holmes, J., and W. Zoller (1996), The elemental signature of transported Asian dust at Mauna Loa observatory, Tellus, Ser. B, 48, 83-92, doi:10.1034/ j.1600-0889.1996.00008.x.

Hopke, P. K., Y. Xie, T. Raunemaa, S. Biegalski, S. Landsberger, W. Maenhaut, P. Artaxo, and D. Cohen (1997), Characterization of the gen stacked filter unit PM10 sampler, Aerosol Sci. Technol., 27, 726-735, doi: 10.1080/02786829708965507.

Hsu, S.-C., S. C. Liu, Y.-T. Huang, S.-C. C. Lung, F. Tsai, J.-Y. Tu, and S.-J. Kao (2008), A criterion for identifying Asian dust events based on Al concentration data collected from northern Taiwan between 2002 and early 2007, J. Geophys. Res., 113, D18306, doi:10.1029/2007JD009574.

Krueger, B. J., V. H. Grassian, A. Laskin, and J. P. Cowin (2003), The transformation of solid atmospheric particles into liquid droplets through heterogeneous chemistry: Laboratory insights into the processing of calcium containing mineral dust aerosol in the troposphere, Geophys. Res. Lett., 30(3), 1148, doi:10.1029/2002GL016563.

Kulkarni, P., S. Chellam, J. B. Flanagan, and R. K. M. Jayanty (2007), Microwave digestion-ICP-MS for elemental analysis in ambient airborne fine particulate matter: Rare earth elements and validation using a filter borne fine particle certified reference material, Anal. Chim. Acta, 599, 170-176, doi:10.1016/j.aca.2007.08.014.

Kumar, A., and M. M. Sarin (2009), Mineral aerosols from western India: Temporal variability of coarse and fine atmospheric dust and elemental characteristics, Atmos. Environ., 43, 4005-4013, doi:10.1016/j.atmosenv. 2009.05.014.

Leidner, S. M., D. R. Stauffer, and N. L. Seaman (2001), Improving shortterm numerical weather prediction in the California coastal zone by dynamic initialization of the marine boundary layer, Mon. Weather Rev., 129, 275-294, doi:10.1175/1520-0493(2001)129<0275: ISTNWP $>2.0$. $\mathrm{CO} ; 2$.

Liu, T. H., F. J. Tsai, S. C. Hsu, C. W. Hsu, C. J. Shiu, W. N. Chen, and J. Y. Tu (2009), Southeastward transport of Asian dust: Source, transport and its contributions to Taiwan, Atmos. Environ., 43, 458-467, doi:10.1016/j. atmosenv.2008.07.066.

Mahowald, N. M., P. Artaxo, A. R. Baker, T. D. Jickells, G. S. Okin, J. T. Randerson, and A. R. Townsend (2005), Impacts of biomass burning emissions and land use change on Amazonian atmospheric phosphorus cycling and deposition, Global Biogeochem. Cycles, 19, GB4030, doi:10.1029/2005GB002541.

Mahowald, N., et al. (2008), Global distribution of atmospheric phosphorus sources, concentrations and deposition rates, and anthropogenic impacts, Global Biogeochem. Cycles, 22, GB4026, doi:10.1029/2008GB003240.

Majestic, B. J., J. J. Schauer, M. M. Shafer, J. R. Turner, P. M. Fine, M. Singh, and C. Sioutas (2006), Development of a wet-chemical method for the speciation of iron in atmospheric aerosols, Environ. Sci. Technol., 40, 2346-2351, doi:10.1021/es052023p.

Marenco, F., et al. (2006), Characterization of atmospheric aerosols at Monte Cimone, Italy, during summer 2004: Source apportionment and transport mechanisms, J. Geophys. Res., 111, D24202, doi:10.1029/ 2006JD007145.

Markaki, Z., K. Oikonomou, M. Kocak, G. Kouvarakis, A. Chaniotaki, N. Kubilay, and N. Mihalopoulos (2003), Atmospheric deposition of inor- ganic phosphorus in the Levantine Basin, eastern Mediterranean: Spatial and temporal variability and its role in seawater productivity, Limnol. Oceanogr., 48, 1557-1568, doi:10.4319/1o.2003.48.4.1557.

McKendry, I. G., J. P. Hacker, R. Stull, S. Sakiyama, D. Mignacca, and K. Reid (2001), Long-range transport of Asian dust to the Lower Fraser Valley, British Columbia, Canada, J. Geophys. Res., 106, 18,361-18,370, doi:10.1029/2000JD900359.

Migon, C., V. Sandroni, and J. P. Bethoux (2001), Atmospheric input of anthropogenic phosphorus to the northwest Mediterranean under oligotrophic conditions, Mar. Environ. Res., 52, 413-426, doi:10.1016/S01411136(01)00095-2.

Mills, M. M., C. Ridame, M. Davey, J. La Roche, and R. J. Geider (2004), Iron and phosphorus co-limit nitrogen fixation in the eastern tropical North Atlantic, Nature, 429, 292-294, doi:10.1038/nature02550.

Morales-Baquero, R., E. Pulido-Villena, and I. Reche (2006), Atmospheric inputs of phosphorus and nitrogen to the southwest Mediterranean region: Biogeochemical responses of high mountain lakes, Limnol. Oceanogr., 51, 830-837, doi:10.4319/1o.2006.51.2.0830.

Moreno, T., X. Querol, A. Alastuey, and W. Gibbons (2008), Identification of FCC refinery atmospheric pollution events using lanthanoid- and vanadium-bearing aerosols, Atmos. Environ., 42, 7851-7861, doi:10.1016/ j.atmosenv.2008.07.013.

Mori, I., M. Nishikawa, T. Tanimura, and H. Quan (2003), Change in size distribution and chemical composition of kosa (Asian dust) aerosol during long-range transport, Atmos. Environ., 37, 4253-4263, doi:10.1016/ S1352-2310(03)00535-1.

Neff, J. C., A. P. Ballantyne, G. L. Farmer, N. M. Mahowald, J. L. Conroy, C. C. Landry, J. T. Overpeck, T. H. Painter, C. R. Lawrence, and R. L. Reynolds (2008), Increasing eolian dust deposition in the western United States linked to human activity, Nat. Geosci., 1, 189-195, doi:10.1038/ ngeo133.

Painter, T. H., A. P. Barrett, C. C. Landry, J. C. Neff, M. P. Cassidy, C. R. Lawrence, K. E. McBride, and G. L. Farmer (2007), Impact of disturbed desert soils on duration of mountain snow cover, Geophys. Res. Lett., 34 L12502, doi:10.1029/2007GL030284.

Park, R. J., et al. (2005), Export efficiency of black carbon aerosol in continental outflow: Global implications, J. Geophys. Res., 110, D11205, doi:10.1029/2004JD005432.

Pekney, N. J., and C. I. Davidson (2005), Determination of trace elements in ambient aerosol samples, Anal. Chim. Acta, 540, 269-277, doi:10.1016/j. aca.2005.03.065

Prospero, J. M. (1999), Long-range transport of mineral dust in the global atmosphere: Impact of African dust on the environment of the southeastern United States, Proc. Natl. Acad. Sci. U. S. A., 96, 3396-3403, doi:10.1073/pnas.96.7.3396.

Psenner, R. (1999), Living in a dusty world: Airborne dust as a key factor for alpine lakes, Water Air Soil Pollut., 112, 217-227, doi:10.1023/ A:1005082832499.

Pupacko, A. (1993), Variations in northern Sierra Nevada streamflow: Implications of climate change, Water Resour. Bull., 29, 283-290.

Seinfeld, J. H., et al. (2004), ACE-ASIA: Regional climatic and atmospheric chemical effects of Asian dust and pollution, Bull. Am. Meteorol. Soc., 85, 367-380, doi:10.1175/BAMS-85-3-367.

Shen, Z. X., J. J. Cao, X. X. Li, Y. Q. Wang, D. M. Jie, and X. Y. Zhang (2006), Chemical characteristics of aerosol particles (PM2.5) at a site of Horqin Sand-land in northeast China, J. Environ. Sci., 18, 701-707.

Sholkovitz, E. R., P. N. Sedwick, and T. M. Church (2009), Influence of anthropogenic combustion emissions on the deposition of soluble aerosol iron to the ocean: Empirical estimates for island sites in the North Atlantic, Geochim. Cosmochim. Acta, 73, 3981-4003, doi:10.1016/j.gca.2009. 04.029 .

Sickman, J. O., J. M. Melack, and D. W. Clow (2003), Evidence for nutrient enrichment of high-elevation lakes in the Sierra Nevada, California, Limnol. Oceanogr., 48, 1885-1892, doi:10.4319/lo.2003.48.5.1885.

Sokolik, I. N., D. M. Winker, G. Bergametti, D. A. Gillette, G. Carmichael, Y. J. Kaufman, L. Gomes, L. Schuetz, and J. E. Penner (2001), Introduction to special section: Outstanding problems in quantifying the radiative impacts of mineral dust, J. Geophys. Res., 106, 18,015-18,027, doi:10.1029/ 2000JD900498.

Swami, K., C. D. Judd, J. Orsini, K. X. Yang, and L. Husain (2001), Microwave assisted digestion of atmospheric aerosol samples followed by inductively coupled plasma mass spectrometry determination of trace elements, Fresenius J. Anal. Chem., 369, 63-70, doi:10.1007/s002160000575.

Taylor, S. R., and S. M. McLennan (1995), The geochemical evolution of the continental crust, Rev. Geophys., 33, 241-265, doi:10.1029/95RG00262. VanCuren, R. A. (2003), Asian aerosols in North America: Extracting the chemical composition and mass concentration of the Asian continental aerosol plume from long-term aerosol records in the western United States, J. Geophys. Res., 108(D20), 4623, doi:10.1029/2003JD003459. 
VanCuren, R. A., and T. A. Cahill (2002), Asian aerosols in North America: Frequency and concentration of fine dust, J. Geophys. Res., 107(D24), 4804, doi:10.1029/2002JD002204.

VanCuren, R. A., S. S. Cliff, K. D. Perry, and M. Jimenez-Cruz (2005), Asian continental aerosol persistence above the marine boundary layer over the eastern North Pacific: Continuous aerosol measurements from Intercontinental Transport and Chemical Transformation 2002 (ITCT 2K2), J. Geophys. Res., 110, D09S90, doi:10.1029/2004JD004973.

Vicars, W. C., J. O. Sickman, and P. J. Ziemann (2010), Atmospheric phosphorus deposition at a montane site: Size distribution, effects of wildfire, and ecological implications, Atmos. Environ., 44, 2813-2821, doi:10.1016/j. atmosenv.2010.04.055.

Wu, G. J., B. Q. Xu, C. L. Zhang, S. P. Gao, and T. D. Yao (2009), Geochemistry of dust aerosol over the Eastern Pamirs, Geochim. Cosmochim. Acta, 73, 977-989, doi:10.1016/j.gca.2008.11.022.

Yin, Y., S. Wurzler, Z. Levin, and T. G. Reisin (2002), Interactions of mineral dust particles and clouds: Effects on precipitation and cloud optical properties, J. Geophys. Res., 107(D23), 4724, doi:10.1029/2001JD001544.
Zhang, Q., J. J. Carroll, A. J. Dixon, and C. Anastasio (2002), Aircraft measurements of nitrogen and phosphorus in and around the Lake Tahoe Basin: Implications for possible sources of atmospheric pollutants to Lake Tahoe, Environ. Sci. Technol., 36, 4981-4989, doi:10.1021/es025658m.

Zhang, Y., and G. R. Carmichael (1999), The role of mineral aerosol in tropospheric chemistry in East Asia: A model study, J. Appl. Meteorol., 38, 353-366, doi:10.1175/1520-0450(1999)038<0353:TROMAI $>2.0 . C O ; 2$.

Zhao, T. L., S. L. Gong, X. Y. Zhang, and I. G. McKendry (2003), Modeled size-segregated wet and dry deposition budgets of soil dust aerosol during ACE-Asia 2001: Implications for trans-Pacific transport, J. Geophys. Res., 108(D23), 8665, doi:10.1029/2002JD003363.

J. O. Sickman, Department of Environmental Sciences, University of California, Riverside, CA 92521, USA. (james.sickman@ucr.edu)

W. C. Vicars, Laboratoire de Glaciologie et Géophysique de l'Environment, Université Joseph Fourier, CNRS, F-38400 St. Martin d'Héres, France. 